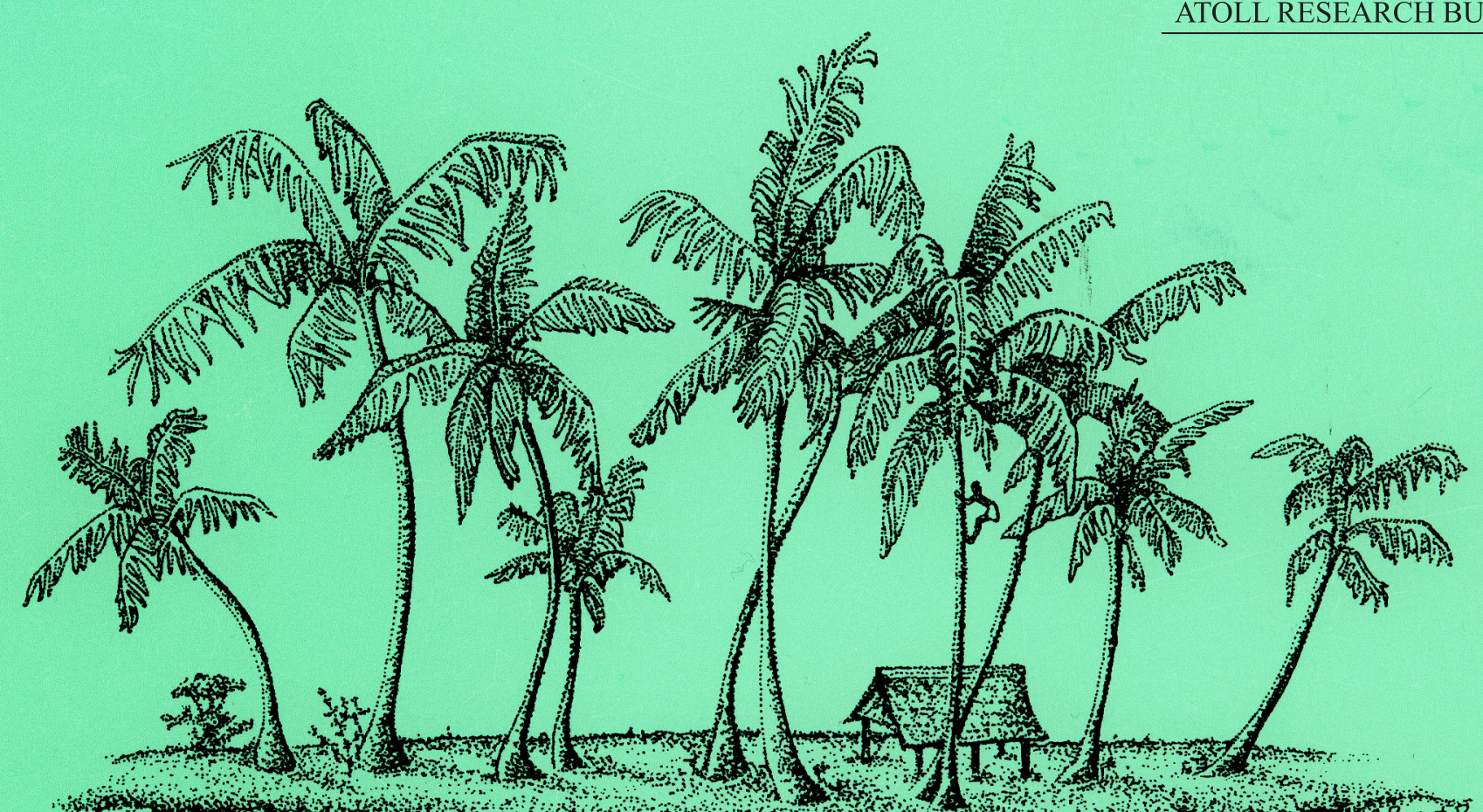

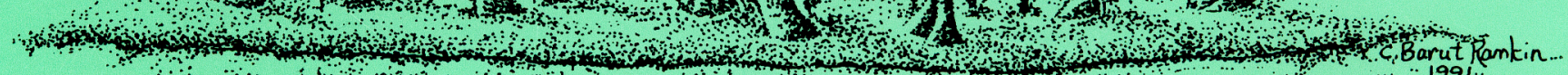

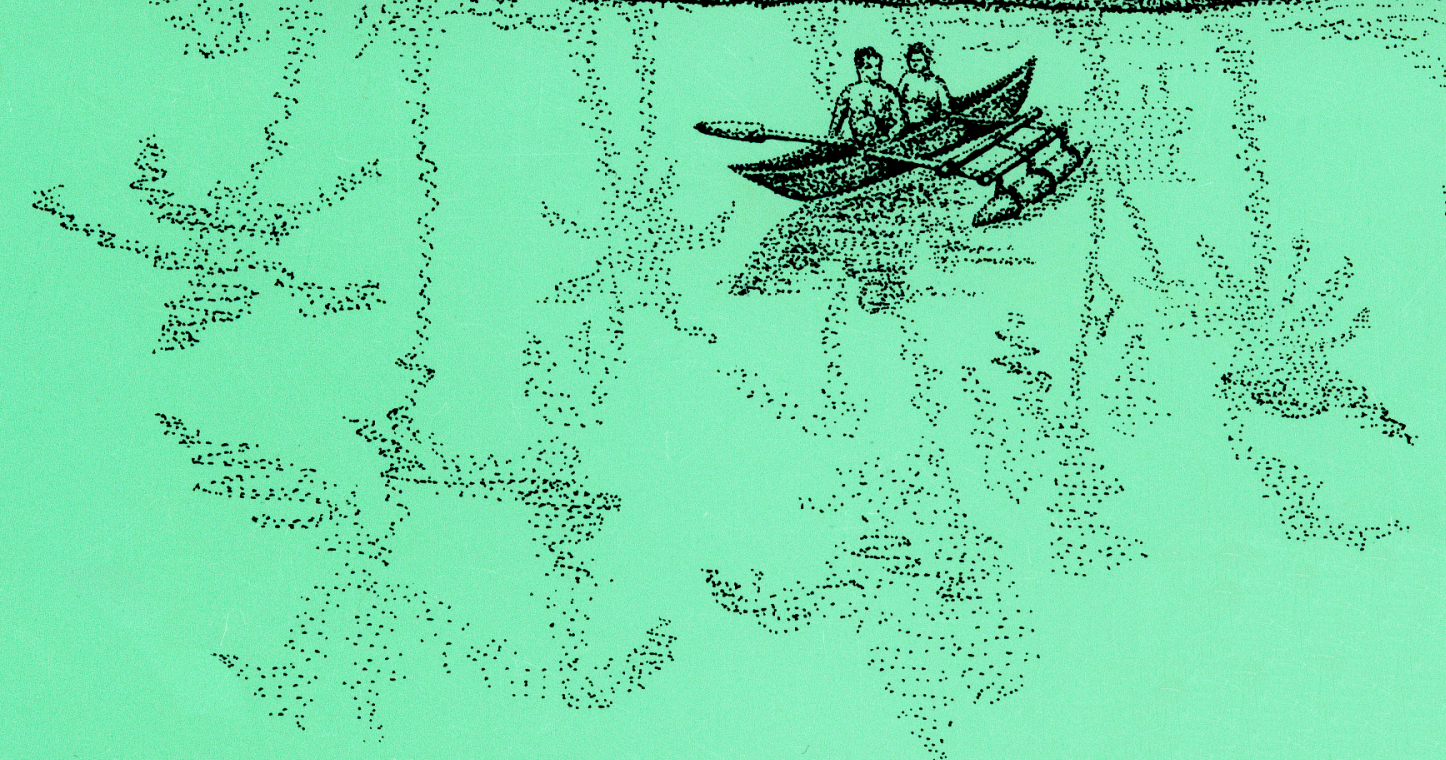

FISHES FROM BASSAS DA INDIA ATOLL

IN THE MOZAMBIQUE CHANNEL

Rudy van der Elst, Simon Chater,

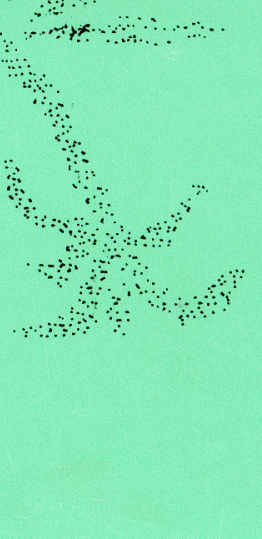

and Dennis King

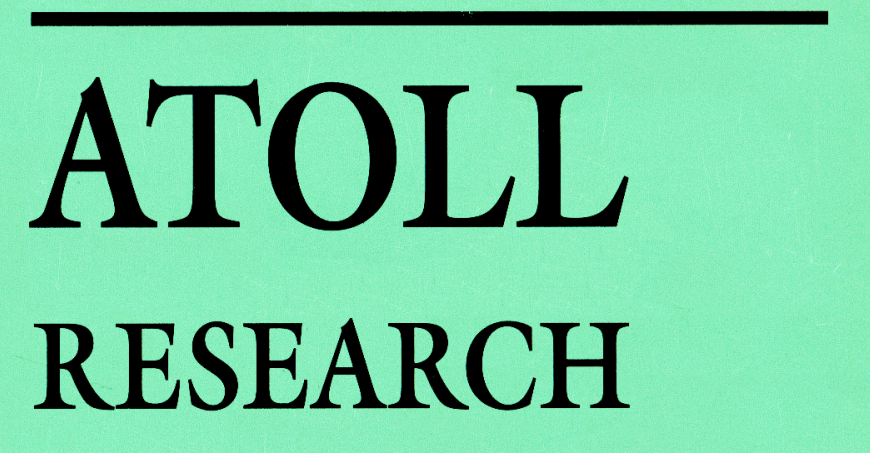

Smithsonian

BULLETIN 



\title{
FISHES FROM BASSAS DA INDIA ATOLL IN THE MOZAMBIQUE CHANNEL
}

\author{
Rudy van der Elst, Simon Chater, \\ and Dennis King
}

Atoll Research Bulletin No. 629 16 August 2021

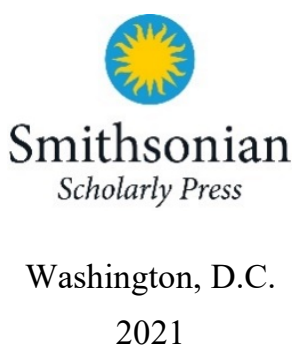


All statements made in papers published in the Atoll Research Bulletin are the sole responsibility of the authors and do not necessarily represent the views of the Smithsonian Institution or of the editors of the bulletin. Articles submitted for publication in the Atoll Research Bulletin should be original papers and must be made available by authors for open access publication under a CCBY-NC-ND license. Manuscripts should be consistent with the "Author Formatting Guidelines for Publication in the Atoll Research Bulletin." All submissions to the bulletin are peer reviewed and, after revision, are evaluated prior to acceptance and publication through the publisher's open access portal (https://smithsonian.figshare.com/ScholarlyPress).

Published by SMITHSONIAN INSTITUTION SCHOLARLY PRESS

P.O. Box 37012, MRC 957

Washington, DC 20013-7012

https://scholarlypress.si.edu

ISSN: 0077-5630 (online)

Copyright (C 2021 by Rudy van der Elst, Simon Chater, and Dennis King

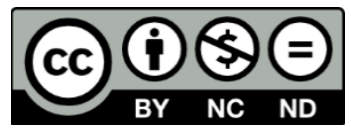

This work is licensed under a Creative Commons Attribution-NonCommercial-NoDerivatives 4.0 International License. 


\section{CONTENTS}

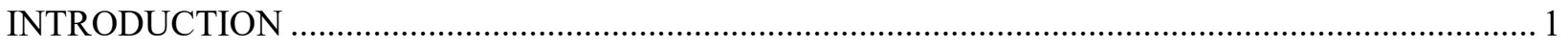

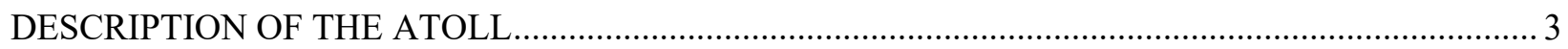

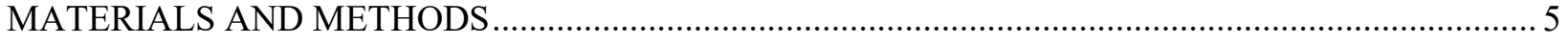

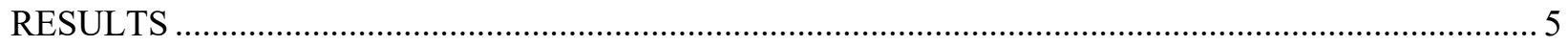

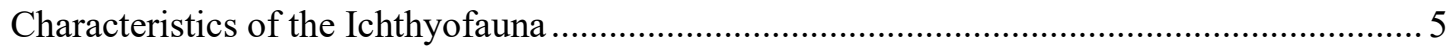

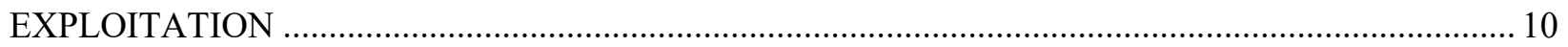

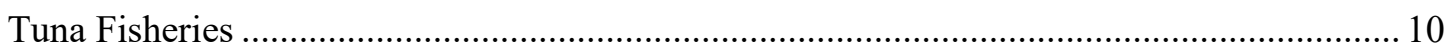

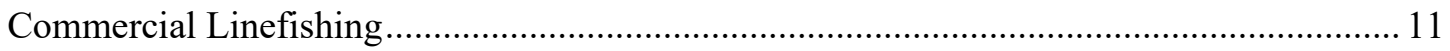

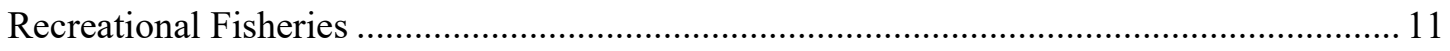

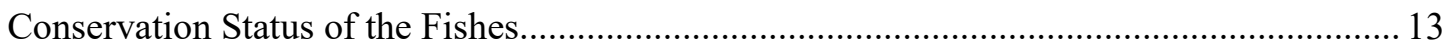

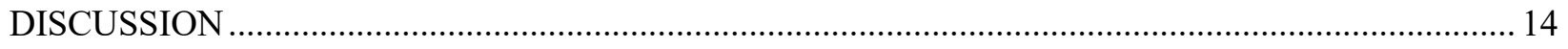

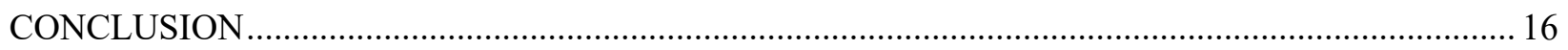

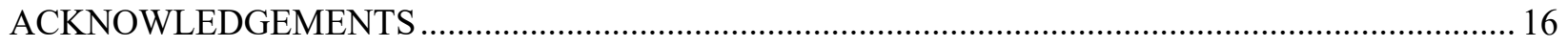

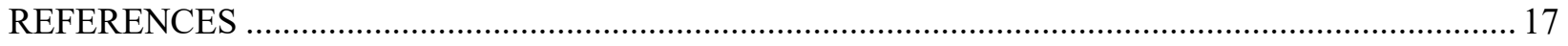

APPENDIX 1: CHECKLIST OF FISHES FROM BASSAS DA INDIA ….......................................... 20 



\title{
FISHES FROM BASSAS DA INDIA ATOLL IN THE MOZAMBIQUE CHANNEL
}

\author{
RUDY VAN DER ELST ${ }^{1 *}$, SIMON CHATER ${ }^{2}$, and DENNIS KING ${ }^{3}$
}

\begin{abstract}
Bassas da India is a remote, uninhabited coral atoll in the West Indian Ocean. Its inaccessibility had historically precluded study of its ichthyofauna until a small group of scientists from the Oceanographic Research Institute in South Africa undertook a two-week biodiversity survey in 1991. Since then, the discourse on climate change has taken on a higher relevance, calling for protection and study of biodiversity hotspots such as Bassas da India. The survey recorded 309 fish species, including a number of vulnerable teleosts and elasmobranchs. As the only published information on the biodiversity of this remote small island, it is intended that this dataset will contribute to increased relevance as an ecological baseline for detecting impacts relating to climate change in the South West Indian Ocean. Each species is listed in terms of its individual abundance, IUCN status as well as its museum and photographic record. Comparisons are made with survey results of other small coral islands in the region, notably Europa Island, revealing several distinct differences in fish diversity. There is evidence that giant groupers will replace sharks as apex predators when there is no local exploitation. A total of 86 species were photographed to confirm identity, and a further 84 species were provided to the South African Institute for Aquatic Biodiversity museum in Grahamstown and also to several international species experts.
\end{abstract}

Keywords: ichthyofauna, climate change, biodiversity, coral reef, apex predator, shark, grouper, South West Indian Ocean, Isles Eparses

\section{INTRODUCTION}

Bassas da India is a remote atoll located centrally in the Mozambique Channel at about $21^{\circ} 28^{\prime} \mathrm{S}$ and $39^{\circ}$ $40^{\prime} \mathrm{E}$ (Figure 1). It is one of several isolated and ancient volcanic cones that lie to the north of the submarine Mozambique plateau. The nearest island is the French possession of Europa, some $110 \mathrm{~km}$ to the southeast. Bassas da India lies at the same latitude as the Bazaruto Archipelago in Mozambique, about $430 \mathrm{~km}$ to the west. Tulear, on the Madagascar west coast, lies about $350 \mathrm{~km}$ eastward.

The existence of Bassas da India (and Europa Island) was first formally documented in 1510 by Pedro Reinel, a Portuguese cartographer. Originally named Baixos da Judia, the atoll of Bassas da India has instilled fear amongst generations of seafarers as an obstacle to ships, and as the cause of great disasters and loss of life (Stuckenberg, 2000). Famed amongst these was the silver-laden Portuguese carrack, Santiago, which struck the reef in 1585. A dozen or more other shipwrecks litter Bassas da India, most having resulted in large loss of life.

\footnotetext{
${ }^{1}$ Oceanographic Research Institute, P.O. Box 10712, Marine Parade, 4056, South Africa

${ }^{2}$ simon@seaworld.org.za

3 dennis@dkstructural.co.za

* Correspondence: rudyvanderelst@,gmail.com
} 


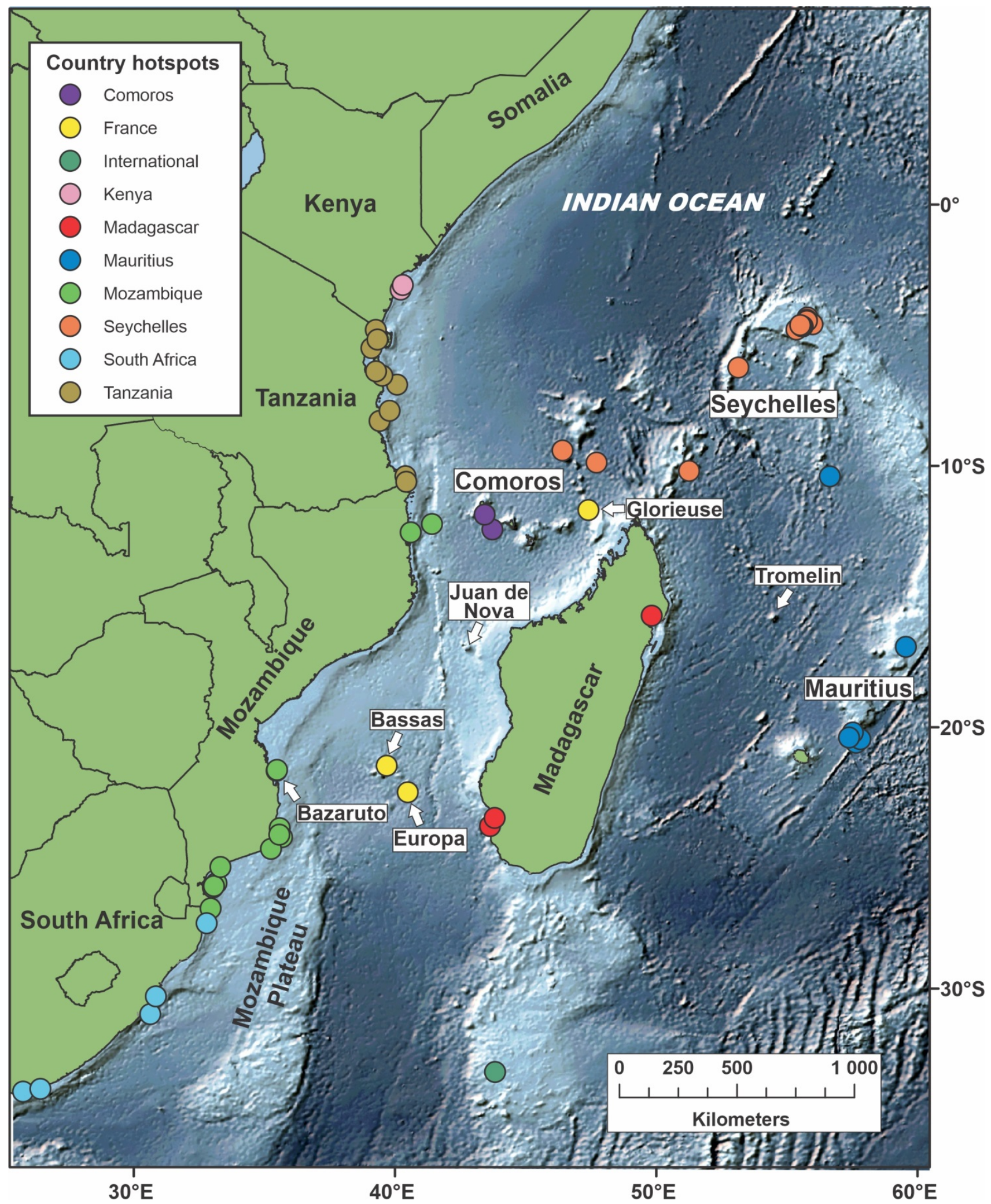

Figure 1. Location of Bassas da India in context to other biodiversity hotspots in the West Indian Ocean (WIO). 
Bassas da India was declared a French possession and was established as a 'Reserve Naturelle' on 17 July 1971 (Harroy, 1972). It is formally gazetted under bylaw ('Arrêté') 13 of 18 November 1975 (République Française, 1975), and forms one of the Isles Eparses, a group of 'Scattered Islands' claimed by France, and which includes Europa, Glorieuses, Juan de Nova and Tromelin. This group forms a part of the French territories of the southern and Antarctic region (Terres Australes et Antarctiques Françaises - TAAF) which comprises Crozet, Kerguelen, St. Paul and Amsterdam islands (in the sub-Antarctic zone) and Adelie Land (Antarctica). However, ownership of several of the 'Scattered Islands' is also asserted by neighbouring countries, including their share of the $640000 \mathrm{~km}^{2}$ Exclusive Economic Zone (EEZ) which France proclaimed in 1978 (République Française, 1978). Although some agreements on this dispute have been reached, several remain unresolved, including Mauritius and Madagascar's claims to Bassas da India (République Française, 1978; Oraison, 2015).

\section{DESCRIPTION OF THE ATOLL}

The Mozambique Channel was formed some 130 Ma with the break-up of Gondwanaland (Braithwaite, 1984). More recently, between 40-50 Ma, volcanic activity around several tectonic boundaries in the South West Indian Ocean $\left(20^{\circ}\right.$ to $\left.22^{\circ} \mathrm{S}\right)$ increased substantially, leading to the creation of a cluster of some 440 seamounts. Most are low and flat-topped, but many have overgrowths of coral on the subsiding summits. Some have formed shallow reef platforms while others have become atolls with low-lying islands, as in the case of Bassas. While this volcanism process remains to be fully understood, differences in the origin of the magma may have dictated the original shape and size of these seamounts (Courgeon et al., 2017).

In his film series The Undersea World of Jacques Cousteau (1966-1967), Jacques Cousteau described Bassas da India as "a perfect atoll, a belt of coral that barely reaches the surface of the sea and is unmarred by a single coconut tree." The atoll is almost circular in shape, has an enclosed lagoon of some $90 \mathrm{~km}^{2}$, measures about $11.4 \mathrm{~km}$ from east to west and $9.9 \mathrm{~km}$ from north to south (Figure 2). A single narrow shallow passage, navigable only by small boat, passes through the reef into the lagoon on the northern side of the atoll. This channel is bounded on one side by a shallow sandbar that is exposed at low spring tide. A maximum depth of $14 \mathrm{~m}$ has been recorded in the lagoon, which is fringed by reef flats of about $300 \mathrm{~m}$ at their widest point. The reef top is dominated by large expanses of bare coral rubble and most of the patch reefs, which abound in the lagoon, consist entirely of dead coral. While this is in part attributable to damage resulting from periodic cyclones that strike Bassas da India, significant coral bleaching mortalities were reported in the region during the 1982-1983 El Niño warming event (Glynn, 1984) and again during the 1998-1999 El Niño warming phase. A number of papers reported on bleaching events as part of the Global Coral Reef Monitoring Network (GCRMN). The severity of coral bleaching in the WIO ranged from $0 \%$ to $99 \%$, depending on the vulnerability of the species, latitude and depth. Trends in measurements expressed as percent coral cover, suggest that vulnerability to bleaching is highly variable, indicating zones of high- and low- vulnerability to future climate change. While inadequate sampling has yet to precisely confirm such zones, the use of remote sensing has assisted in the creation of at least two mappings of zones at risk to WIO reefs (Burke et al., 2011; Maina et al., 2008), suggesting that Bassas da India falls within a medium-risk zone (Wilkinson, 2000; Obura et al., 2000; Obura, 2015).

The prevailing winds at Bassas da India are the southeast trade winds which continually pound the surf on the southern and eastern side of the atoll. The atoll is occasionally lashed by tropical cyclones from the south-east during the summer months of December to March. In addition, periodic cyclones migrate southward down the Mozambique Channel and strike the atoll. The destructive effects of these violent weather systems within the shallow waters of the atoll are evident from the large, broken blocks of dead coral upswept over the reef top.

Atoll Research Bulletin, No. 629 


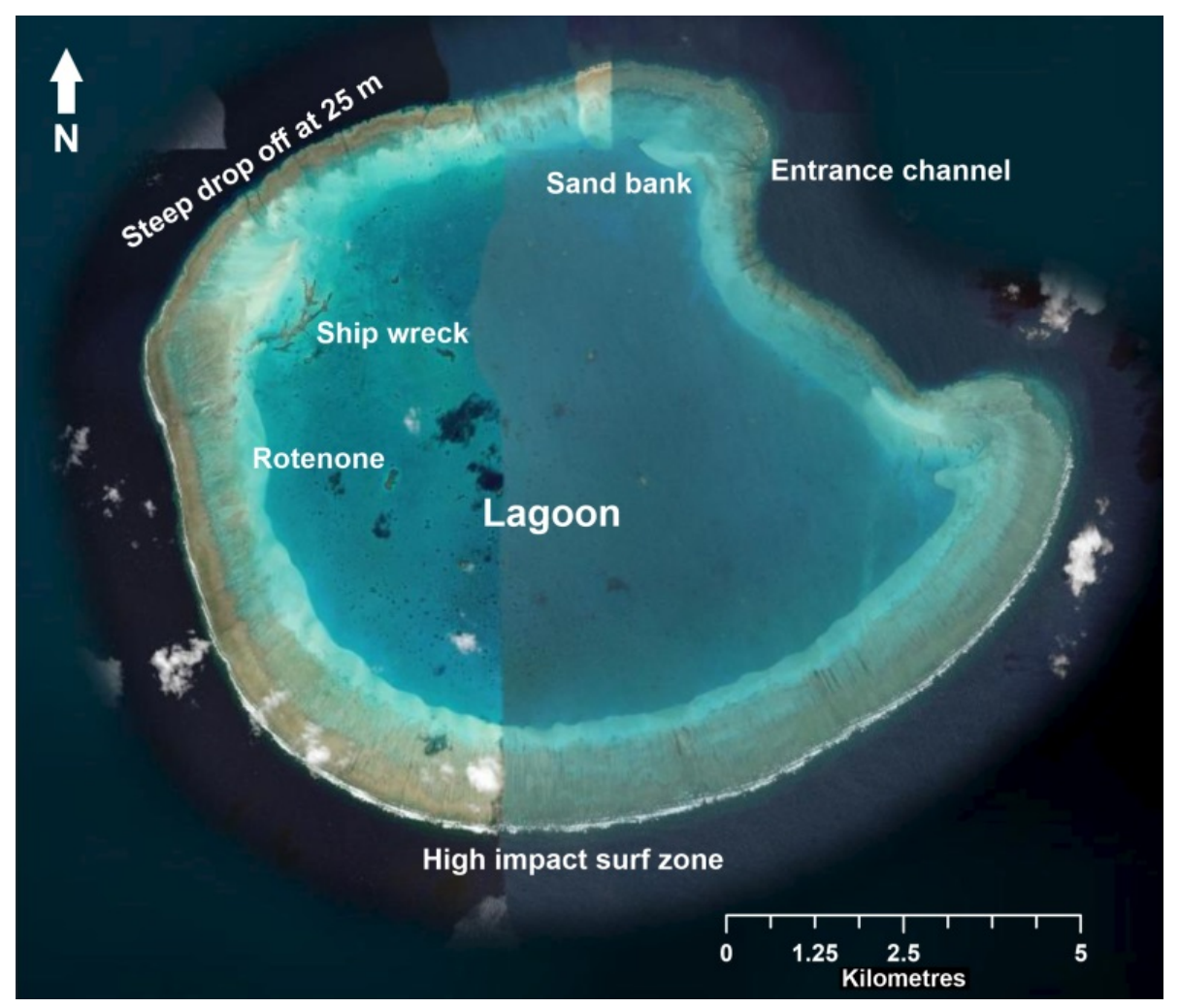

Figure 2. Google Earth image of Bassas da India atoll at low tide. Image (C Esri, Maxar, GeoEye, Earthstar Geographics, CNES/Airbus DS, USDA, USGS, AeroGRID, IGN, and the GIS User Community. Imagery date $23 / 03 / 2021.21^{\circ} 28^{\prime \prime} \mathrm{S}, 39^{\circ} 40^{\prime \prime} \mathrm{E}$.

The south and east side reef front is incised by numerous spur and groove formations (Duce et al., 2014) which open out at a depth of about $10 \mathrm{~m}$ and clearly dissipate heavy wave action, providing a measure of protection to the inner zone of corals. The surge through these gullies at the reef edge during periods of heavy swell is enormous and coral growth here is limited to encrusting species. The reef slopes steeply downwards at an angle of $\sim 20^{\circ}$, to a $450 \mathrm{~m}$ deep ledge. Beyond the ledge, the sea floor drops to a maximum of $3,000 \mathrm{~m}$ within $5 \mathrm{~km}$ off the atoll. The drop-offs on the sheltered northwest side of the atoll sustain profuse plate coral (up to $2 \mathrm{~m}$ in diameter) and fish communities. The reef-top drops vertically to a plateau at 15 to $25 \mathrm{~m}$, which varies in width up to $80 \mathrm{~m}$ before dropping off precipitously to the ocean floor. Depths of $1000 \mathrm{~m}$ have been recorded within $2 \mathrm{~km}$ of the atoll; relative to its overall size, there is remarkably little shallow shelf area.

Notable amongst the coral species in more sheltered locations throughout the lagoon, are Ceriotopera hystrix and Stylophera pistillata. These so-called "weed corals" are fragile but fast-growing pioneer species. Frequent storms break up these species and deposit their fragments on the lagoon bottom, where they rapidly form new coral clusters, each providing a niche for small fish and invertebrates. Algae are confined to short encrusting varieties, while seagrasses appear to be very scarce or completely lacking, hence limiting the accretion of the sand substrate that could otherwise occur.

Sea surface water temperatures (SSTs) in the Mozambique Channel are seasonal and range from $20^{\circ}$ to $30^{\circ} \mathrm{C}$. However, complex eddy formation and anomalies, induced by wind, present a complicated picture (Han et al., 2019). In summer, when SSTs can remain at their maximum for several days, there is a risk of coral bleaching, as in the 1998 event (Obura, 2015). At the time of this study in winter, the prevailing water temperature in the lagoon after sunset was $24^{\circ} \mathrm{C}$. It has already been established that the West Indian Ocean (WIO) is warming faster than any other tropical sea (Pfeiffer et al., 2017; Zinke et al., 2019). Based on extensive coral coring at a number of sites in the WIO including Europa, it has been shown that the general 
SST in the Mozambique Channel has substantially increased over the past 334 years. The coral paleotemperature proxy data, which is based on the ratio of $\mathrm{Sr} / \mathrm{Ca}$, has been validated with direct measurements of SST since 1880, confirming the accuracy of the older core data (Zinke et al., 2019). The tides at Bassas are diurnal with a maximum range measured at spring tide during our visit of about $3.5 \mathrm{~m}$. At high tide, the atoll is completely submerged with only a few large chunks of coral visible that had presumably been cast onto the reef by storms.

That Bassas is remote and a notorious area for shipwrecks has meant that exploitation of reef fishes at this site in comparison to other sites in the region has been exceptionally low. This means that the fishing mortality is in effect $\mathrm{F}=0$, so that stocks can be considered near pristine. There have been periodic but rare commercial linefishing trips, some of which permitted a scientist to be on board. Recreational fishing in the area developed with the advent of GPS technology, mostly originating from Mozambique by South African anglers. However, the distance offshore and the French jurisdiction limited this activity. The only published information on the natural history of Bassas is that which attempts to calculate fisheries data as part of the 'The Sea Around Us' programme, which produced a first estimate of marine fisheries in the Eparses islands by review and extrapolation of existing literature and records (Le Manach and Pauly, 2015).

\section{MATERIALS AND METHODS}

Bassas da India is an exceptionally difficult place to visit due to its remote location, lack of safe anchorage, powerful currents, and frequent strong wave action. However, over the years, a number of staff from the Oceanographic Research Institute (ORI) in South Africa paid brief opportunistic visits to the atoll, e.g., when participating in research cruises, as observers on fishing boats or during a two-week expedition in June/July 1991. During these visits, limited collections and recording of fish as well as invertebrates, corals and seaweeds were made. All the material collected has been placed in reputable and appropriate museums.

Fishes were recorded in more detail, although the collecting did not in any way represent an exhaustive and quantitative assessment that would be required for a full biodiversity assessment. Records of line-caught catches were obtained from limited commercial fishing trips. During the two-week survey in 1991, material was collected from several sites using a variety of techniques. The reef top was sampled at low tide using small amounts of rotenone, hand nets, angling and spearing. In the lagoon and over drop-offs to $25 \mathrm{~m}$, hand nets, angling and spearing were used. Photographs, as well as visual sightings were documented and used to identify some of the specimens, but only if there was agreement between at least two knowledgeable divers.

References used for the identification of fish collected, or seen, were by Allen and Steene (1987), Burgess, Axelrod and Hunziker (1990), Compagno (1984a; 1984b), Fischer and Bianchi (1984), Heemstra and Randall (1993), Masuda et al. (1984), Randall and Heemstra (1991), Smith and Heemstra (1986) and Randall (1998). Some of the specimens were dispatched to experts for identification. Where indicated, 35 $\mathrm{mm}$ colour transparencies of freshly dead specimens were catalogued in the slide collection of the ORI's library. These have since been digitised. Measurements recorded of collected specimens included total length (TL) and/or fork length (FL). Note that the taxonomy applied in this study relates to that in use at the time of the surveys so as to support comparisons. For example, the Serranidae have now been largely allocated to the Epinephelidae.

\section{RESULTS}

\section{Characteristics of the Ichthyofauna}

To our knowledge no other collections or actual recordings of fish have been made at Bassas da India, therefore this report represents the first 'published record' of the atoll's ichthyofauna. Le Manach and Pauly (2015) published estimates of landings for Bassas based on extrapolations from various data sources. However, a survey of fishes of the nearby Europa Island had been conducted in 2013 (Fricke et al., 2013) following an earlier study by Fourmanoir (1952).

Atoll Research Bulletin, No. 629 
A total of 309 species, comprising 49 families, was recorded during the six days of sampling at Bassas (Table 1). The overall detailed list of species is presented in Appendix 1, which includes all species recorded by the different techniques, i.e., collecting, photography, fishing, and visual observation. Some 330 individual fish specimens comprising 75 species were dispatched to expert ichthyologists around the world for assistance with identification. The balance of specimens was placed in the Rhodes University Smith Institute (RUSI) collection in Grahamstown, now the South African Institute of Aquatic Biodiversity.

Table 1. Families and number of fish species recorded at Bassas da India during a six-day expedition conducted in June/July 1991

\begin{tabular}{|lc|}
\hline Family & Number of Species \\
\hline Carcharhinidae & 6 \\
Myliobatidae & 1 \\
Mobulidae & 1 \\
Dasyatidae & 1 \\
Muraenidae & 4 \\
Clupeidae & 1 \\
Chanidae & 1 \\
Synodontidae & 3 \\
Carapdidae & 4 \\
Atherinidae & 1 \\
Belonidae & 1 \\
Holocentridae & 14 \\
Syngnathidae & 1 \\
Scorpaenidae & 6 \\
Caracanthidae & 2 \\
Kuhlidae & 1 \\
Serranidae & 22 \\
Pseudochromidae & 2 \\
Priacanthidae & 2 \\
Apogonidae & 11 \\
Haemulidae & 2 \\
Lutjanidae & 9 \\
Caesionidae & 5 \\
Lethrinidae & 8 \\
Nemipteridae & 1 \\
Kyphosidae & 1 \\
\hline
\end{tabular}

\begin{tabular}{|lc|}
\hline Family (cont.) & Number of Species (cont.) \\
\hline Mullidae & 8 \\
Malacanthidae & 2 \\
Pomacanthidae & 7 \\
Chaetodontidae & 18 \\
Carangidae & 8 \\
Cirrhitidae & 3 \\
Pempheridae & 1 \\
Pomacentridae & 22 \\
Labridae & 41 \\
Scaridae & 11 \\
Sphyraenidae & 2 \\
Mugiloididae & 2 \\
Blennidae & 11 \\
Gobiidae & 10 \\
Acanthuridae & 21 \\
Zanclidae & 1 \\
Siganidae & 2 \\
Scombridae & 5 \\
Balistidae & 10 \\
Monacanthidae & 3 \\
Ostracidae & 2 \\
Tetraodontidae & 7 \\
Diodontidae & 1 \\
\hline & \\
Total species $=\mathbf{3 0 9}$ & \\
Total families $=\mathbf{4 9}$ & \\
\hline
\end{tabular}

The abundance and species distribution of fish varied considerably over the entire area of Bassas da India. Highest diversity was recorded on the sheltered northwest side of the atoll, in stark contrast to the exposed and rough southeast side, which displayed a lower abundance and diversity of fishes. The lagoon was generally not prolific in fish, except associated with clusters of coral deposited there by cyclones, which provided niches for a variety of small coral reef fishes. While encrusting and tufted coralline algae were plentiful, the absence of seagrasses and fleshy seaweeds in the lagoon no doubt contributed to a relatively lower abundance of herbivorous fishes.

The geographic ranges allocated to each fish species recorded at Bassas da India encompassed IndoPacific, Indo-West Pacific, Indian Ocean, Western Indian Ocean, Indo-Central Pacific and Circumtropical, after Smith and Heemstra (1986). The species not covered in this reference were taken from FAO Species 
Identification Sheets for Fishery Purposes; Western Indian Ocean Vols. 1-4 (1984), Masuda et al. (1984) and Winterbottom et al. (1989). Indo-Pacific species (43\%) and Indo-West Pacific species (33\%) comprised the bulk of the fish species observed at Bassas da India. Indian Ocean endemics contributed 9\%. The identities of seven species proved problematic and some remain undescribed, including five gobies, one pomacentrid (Chrysiptera sp.) and one dasyatid (Himantura sp. marginatus?).

The species assemblage of Bassas da India is typically that of a coral reef ecosystem, dominated by Labridae (41 species/13.2\%), Pomacentridae (22 species/7.1\%), Serranidae (21 species/6.8\%), Scaridae (11 species/3.5\%), Chaetodontidae (18 species/5.8\%) and Acanthuridae (21 species/6.8\%) (Table 1). Historically, the Mozambique Current was considered to be a permanent, contiguous and open-ended link between the South Equatorial Current and the Agulhas Current. However, this was shown to be erroneous and oversimplified, when in fact the Mozambique Channel may be hydrologically more homogeneous than originally believed (Lutjeharms et al., 2006). Considering the relatively small distances between the atolls, especially Bassas and Europa, it is expected that the ichthyofauna of other coral reef sites in the region are

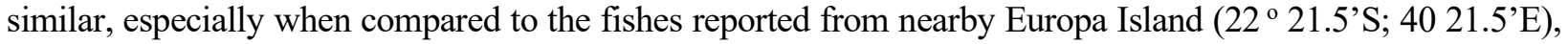
a mere $115 \mathrm{~km}$ to the southeast (Fourmanoir 1952, Fricke et al., 2013). In a more or less similar sampling period and methodology, Fricke et al. (2013) reported a total of 389 species in 62 families; similar to Bassas, the largest families being the Labridae (47 species/12.1\% of total), Pomacentridae (35 species/9.0\%), Serranidae (30 species/7.7\%), Gobiidae and Acanthuridae (24 species each, 6.2\%), and Chaetodontidae (21 species/5.1\%).

Although the top families appear reasonably common between the two atolls, in the case of Europa, there were ten additional families not recorded at Bassas, while conversely, 6 families were found at Bassas but not on Europa. Collectively, this means that the total number of families for the two sites combined is 72 with only 57 of these families common to both sites - i.e., $79.1 \%$ similarity in terms of families.

The species recorded from Bassas da India fall into 49 families, with half the total number of species occurring within only seven families. At Bazaruto, the 306 species recorded belong to 69 families, with 12 families accounting for 50\% of the species (van der Elst and Afonso, 2009). The larger number of families probably reflect the wider range of habitats sampled in the Bazaruto Archipelago. On the coral reefs in the iSimangaliso Wetland Park (St Lucia MPA, KwaZulu-Natal Province, South Africa) the 405 species recorded fall into 70 families, with only eight families making up half the species. In all cases, the Labridae are the dominant family in terms of number of species. However, there are some notable differences (Table 2). While there is a reasonable similarity in the families present, the species within those families are quite different. For example, comparing the species between Bazaruto and Bassas indicates that only 1/3 of the combined list of 448 species are common to both localities. Several families which are common to both have entirely different species compositions. For example, the butterflyfishes are much more diverse at iSimangaliso and Geyser Reef than the other sites, while elasmobranchs are more diverse at the mainland locations (Table 2).

Despite the apparent congruency in fish families, this is not necessarily reflected when comparison is made at the species level. Hence, while the Bassas and Europa surveys reported 309 and 389 species respectively, the Bassas ichthyofauna accounted for 147 species not reported from Europa, while Europa had an additional 203 species over Bassas. This meant that these two sites represented 534 species in total, out of which only $167(32 \%)$ were common to both atolls. This can be further investigated by analysing the differences in species composition within families. Taking the top 15 families is revealing (Table 3). For example, Labridae are reported to have 41 and 42 species for Bassas and Europa respectively, making it seem congruent. But this may be misleading as only 28 of these are common to both sites $(-50.9 \%)$, raising the total number of labrids combined to 55 species. Overall, about $40 \%$ of the families reported comprised species common to both sites, meaning that almost $2 / 3$ of the species are confined to either one of those atolls (Table 3 ).

If the same exercise is done comparing Bassas with Juan de Nova ichthyofauna (Chabanet and Durville, 2005), then the composition is closer at $66 \%$ common species, with 15 families at $100 \%$ similarity.

Atoll Research Bulletin, No. 629 
Table 2. The dominant fish families (including elasmobranchs) expressed as number of species recorded for several WIO coral reef sites

\begin{tabular}{|l|c|c|c|c|c|c|}
\hline & Bassas $^{\mathbf{1}}$ & Europa $^{\mathbf{2}}$ & iSimangaliso $^{\mathbf{3}}$ & Bazaruto $^{\mathbf{4}}$ & $\begin{array}{c}\text { Geyser } \\
\text { Reef }^{5}\end{array}$ & $\begin{array}{c}\text { Juan de } \\
\text { Nova }^{\mathbf{6}}\end{array}$ \\
\hline Serranidae & 21 & 30 & 27 & 9 & 23 & 24 \\
\hline Pomacentridae & 22 & 34 & 20 & 16 & 36 & 30 \\
\hline Labridae & 41 & 40 & 45 & 33 & 38 & 41 \\
\hline Scaridae & 11 & 10 & 7 & 6 & 14 & 12 \\
\hline Chaetodontidae & 18 & 21 & 21 & 9 & 20 & 18 \\
\hline Acanthuridae & 21 & 23 & 21 & 11 & 23 & 24 \\
\hline Lethrinidae & 8 & 6 & 13 & 7 & 6 & 8 \\
\hline Lutjanidae & 9 & 14 & 21 & 11 & 7 & 10 \\
\hline Carangidae & 8 & 11 & 23 & 12 & 7 & 9 \\
\hline Holocentridae & 14 & 9 & 7 & 7 & 13 & 6 \\
\hline Sparidae & 0 & 2 & 16 & 2 & 0 & 0 \\
\hline Elasmobranch & 9 & 9 & 25 & 14 & 7 & 11 \\
\hline
\end{tabular}

${ }^{1}$ This study.

${ }^{2}$ Fricke et al., 2013.

${ }^{3}$ Chater et al., 1993.

${ }^{4}$ van der Elst and Afonso, 2009.

${ }^{5}$ Chabanet, 2002.

${ }^{6}$ Chabanet and Durville, 2005.

Table 3. Top 15 families from Bassas and Europa atolls, indicating their low number of species common to both localities

\begin{tabular}{|l|c|c|c|c|c|}
\hline \multirow{2}{*}{ Family } & \multicolumn{4}{|c|}{ Number of Species } & \multirow{2}{*}{$\begin{array}{c}\text { \% } \\
\text { Common }\end{array}$} \\
\cline { 2 - 5 } & Bassas & Europa & Total & Common & 50.9 \\
\hline Labridae & 41 & 42 & 55 & 28 & 40.0 \\
\hline Pomacentridae & 22 & 35 & 40 & 16 & 28.6 \\
\hline Serranidae & 21 & 24 & 35 & 10 & 2.9 \\
\hline Gobidae & 10 & 26 & 35 & 1 & 33.3 \\
\hline Acanthuridae & 18 & 22 & 30 & 10 & 72.7 \\
\hline Chaetodontidae & 18 & 20 & 22 & 16 & 28.6 \\
\hline Blennidae & 11 & 16 & 21 & 6 & 23.5 \\
\hline Scaridae & 11 & 10 & 17 & 4 & 12.5 \\
\hline Apogonidae & 11 & 7 & 16 & 2 & 46.7 \\
\hline Holocentridae & 14 & 9 & 15 & 7 & 60.0 \\
\hline Lutjanidae & 10 & 15 & 15 & 9 & 46.2 \\
\hline Carangidae & 8 & 12 & 13 & 6 & 66.7 \\
\hline Balistidae & 10 & 11 & 12 & 8 & 40.0 \\
\hline Lethrinidae & 8 & 6 & 10 & 4 & 66.7 \\
\hline Pomacanthidae & 7 & 8 & 9 & 6 & \\
\hline
\end{tabular}


Clearly it can be risky to compare or assess a coral reef ichthyofauna at the family level only, as we have shown the variability that there may be in the individual family's species mix. Yet families of fishes are generally considered to have similar features and habitat requirements, so that they can be useful in many cases where a semi-quantitative comparison is required or as a proxy for some specific environmental condition. The fish species reported here can broadly be grouped into five trophic categories: carnivores, omnivores, herbivores, planktivores and symbionts (Table 4). Comparisons can thus be made over time or between results reported from different localities (Figure 1): Bassas da India, Europa $\left(22^{\circ} 22^{\prime} \mathrm{S} ; 4^{\circ} 22^{\prime} \mathrm{E}\right.$ ),

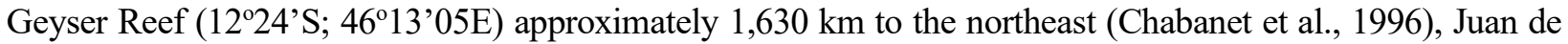
Nova $\left(17^{\circ} 03\right.$ 'S; $\left.42^{\circ} \mathrm{E}\right)$ approximately $750 \mathrm{~km}$ to the northeast, the Bazaruto Archipelago (21 $\left.37^{\prime} \mathrm{S} ; 35^{\circ} 28^{\prime} \mathrm{E}\right)$ $430 \mathrm{~km}$ to the west (van der Elst and Afonso, 2009) and the iSimangaliso Wetland Park ( 27'36'S; 32 $41^{\prime}$ 'E) $966 \mathrm{~km}$ to the southwest (Chater et al., 1993).

Table 4. Percent trophic composition of fishes recorded from several WIO sites

\begin{tabular}{|l|c|c|c|c|c|c|}
\hline $\begin{array}{l}\text { Trophic } \\
\text { Category }\end{array}$ & Bassas $^{\mathbf{1}}$ & Europa $^{\mathbf{2}}$ & Geyser $^{\mathbf{3}}$ & $\begin{array}{c}\text { Juan de } \\
\text { Nova }^{4}\end{array}$ & Bazaruto $^{\mathbf{5}}$ & iSimangaliso $^{\mathbf{6}}$ \\
\hline Carnivores & 73 & 55 & 78 & 73 & 63 & 55 \\
\hline Omnivores & 12 & 26 & 15 & 11 & 21 & 21 \\
\hline Herbivores & 8 & 15 & 7 & 16 & 10 & 8 \\
\hline Planktivores & 6 & 5 & 1 & 6 & 6 & 14 \\
\hline Symbionts & 2 & 2 & 1 & 1 & 1 & 2 \\
\hline
\end{tabular}

${ }^{1}$ This study.

${ }^{2}$ Fricke et al., 2013.

${ }^{3}$ Chabanet et al., 1996.

${ }^{4}$ Chabanet and Durville, 2005.

${ }^{5}$ van der Elst and Afonso, 2009.

${ }^{6}$ Chater et al., 1993.

While these figures are approximations, it is interesting to note that herbivores are of lower diversity at the more oceanic islands of Bassas da India and Geyser. In contrast, regions closer to the continental coast appear to have a higher diversity of plant-eating species.

Apex predators are known to have a strong influence on the structure and dynamics of marine ecosystems, especially in coral reefs, where groupers and sharks often compete for the top spot (Domeier, 2016) and where removal of one apex predator may trigger a trophic cascade, ultimately favouring herbivores. Analysis of such assemblages can be a useful tool in evaluating the protected status of a reef system (Frisch et al., 2016, Anderson et al., 2014). In the case of Bassas, there was an overwhelming presence of large groupers, especially E. tukula and E. lanceolatus. Sharks were scarce and much less common at Bassas than at the other sites, including the smaller reef sharks $(C$. wheeleri, $C$. melanopterus and T. obesus) except for a few specimens on the outer drop off. Yet, these species have been recorded from all the other sites reviewed, often as common or abundant. One explanation is the dominant presence of large groupers which, as competing apex predators, are believed to 'attack' sharks that venture close to the reef and in the lagoon. Certainly, the food resources of the two groups are similar and there is compelling evidence that groupers will eat reef sharks of up of up to one metre (Randall, 1977). Such behaviours were witnessed in a captive situation by two of the authors (RP \& SC) as well as J Ballard, chief curator at Durban SeaWorld (see Box 1). 


\section{Box 1}

Report to SAAMBR Council Meeting: 1991

\section{Zambesi shark and Brindle Bass interaction}

Some years ago, in Durban's Seaworld complex, we had a problem with predation in our main large fish tank. In our shark tank, originally built for experiments to observe the reaction of sharks to netting and other barriers, we had two super aggressive Zambesi sharks (C. leucas). They had grown up from pups caught in 1980 into adults weighing about $240 \mathrm{~kg}$ each. They systematically killed every other shark that was introduced from the wild. So, we had a display problem being stuck with only one species.

Simultaneously we had a super hungry $(>220 \mathrm{~kg})$ giant brindle bass (grouper; E. lanceolatus) in the main fish tank. He had lived there for several years but had taken to eating any species that was under about $10 \mathrm{~kg}$ and newly introduced, including dusky and milk sharks up to $1 \mathrm{~m}$ in length.

So, we had a double problem! After much deliberation we decided to risk the grouper by moving it to the shark tank and hoping that it would survive.

When the day came for the move, we feared a bloodbath. The grouper was unceremoniously dumped into the shark tank, a totally new environment for it. In a flash the Zambezis attacked, at first by bumping into the grouper with great speed, knocking it around. We had long poles to see if we could avoid a disaster. After about 10 minutes, the grouper recovered and while he had a bruised flank, he faced the next shark head-on and raised his dorsal fin spines. For the next few hours, the grouper attacked the sharks to a point where we were concerned that we might lose them. The grouper rammed into the sharks with his band of teeth doing considerable damage. For the next 4-5 years the grouper was very clearly dominant in the tank. Every time one of the sharks swam close to the grouper, he would raise his spines and the shark would veer away.

Eventually, at dawn one morning in 1991, the tank was red with blood, etc. The sharks had had their day. The grouper was no more, only his head (weighing $115 \mathrm{~kg}$ !) remained. Bassas is exceptionally endowed with huge groupers, some very aggressive, and one of us was attacked when releasing a live fish overboard. He still has a scar to prove it.

Are the groupers skewing the ichthyofauna or are they a stabilising factor?

\section{EXPLOITATION}

While Bassas da India is a very remote atoll and thus not expected to be under much fisheries pressure, it also follows that the unexploited levels of fish stocks present a strong lure for some fishers. Indeed, Bassas has been identified as a regional biodiversity hotspot and could serve as a future indicator in the advance of climate change (Everett and van der Elst, 2015). This report draws together some of the modest but important data sets, thereby documenting historic near-pristine conditions in which levels of reef fishing mortality $(\mathrm{F})$ will be zero.

\section{Tuna Fisheries}

Bassas is located at the southern zone of the large tuna fleets that operate in the WIO. While these fleets are flagged in several countries, the main fleet operates out of Seychelles. However, considering the economic zone claimed by France in relation to Bassas da India, tuna vessels are obliged to submit catch records to the French authorities. The region falls under the Indian Ocean Tuna Commission (IOTC), which coordinates research, shares catch information and in future, plans to manage the fisheries through quota allocations. It follows that vessels will at some stage be harvesting in the economic zone of the atoll, although available records indicate that the southern Mozambique Channel is not a preferred tuna 
fisheries ground (IOTC 2020). It is furthermore likely that there has been some illegal, unreported, and unregulated (IUU) fishing in the area, especially by pelagic longliners (Dez Willens, pers. comm.).

\section{Commercial Linefishing}

It is believed, with a reasonable level of certainty, that only two commercial linefish boats have ever operated at Bassas before 2000, and none since. These were the MV Jenny Lee (Capt. Dez Willens) based in Durban and the MV Gilbert Guy (Capt. Roger Maurice) based in Mayotte. The Durban-based operation periodically made exploratory fishing trips to Mozambique waters and on rare occasions fished at one or more of the Eparses islands with three or four trips to Europa and Bassas. The Gilbert Guy ran a profitable operation of buying lobsters (Panulirus ornatus) (and other products) from rural fishers in Madagascar for re-sale in Mayotte. As a Breton fisherman, Maurice would take regular trips to Geyser Reef and once or twice to Europa and Bassas. The Durban operation was well organised with a strong crew of up to 20 fishermen (Figure 3), while the Mayotte operation mostly involved only the skipper and his wife. On one such trip from Durban, a researcher accompanied the expedition [RvdE] and kept brief records. The landings of these linefish operations were spectacular in comparison to fishing in their traditional Mozambique and South Africa grounds, catching up to 30 tons of reef fish by rod and line in six days. The species composition of catches during the earlier visits (1988) were strongly dominated by Serranidae, considerably in excess of $50 \%$ by weight. Most important species were Epinephelus tukula, Plectropomus laevis and P. punctatus. One such catch, taken at Bassas and Europa, included a large number of E. tukula, some of which were sampled and measured to indicate their large size, with all specimens in excess of one metre (Figure 4).

Analysis of catches from subsequent fishing trips revealed a notable decrease in these species to less than $20 \%$ of the total catch, with smaller serranids and species such as bohar snapper (Lutjanus bohar) predominating. It was evident that the large resident predators had been the first removed from the system, including Endangered IUCN Red Listed species such as the humphead wrasse, Cheilinus undulatus.

\section{Recreational Fisheries}

Due to the paucity of recreational fishing data from Bassas, an experiment was conducted during the survey in 1991. The scientific complement on board the research vessel included six experienced recreational anglers. These anglers were divided into two groups (A \& B) and at every opportunity, they were encouraged to fish as if they were tourist anglers, except that they maintained comprehensive records to estimate the abundance and nature of the species present. Only artificial lures were used. The results were expressed as catch per unit effort (CPUE) (i.e., number of fish caught per angler per hour). Ranking the CPUE provides a relative insight into the dominant carnivorous species present. A total of 24 species and 1,495 individual fish were recorded, dominated by L. bohar, Caranx melampygus and $C$. ignobilis (Figure 5).

In the case of Group A, their fishing location was confined to sites which had been pre-determined from an overall grid map of the atoll divided into minute squares, so as to spread the effort. Group B was free to fish in any area of the atoll. All fish were measured before being released, and all lengths were converted to weights using relevant length-weight equations (Table 5). 


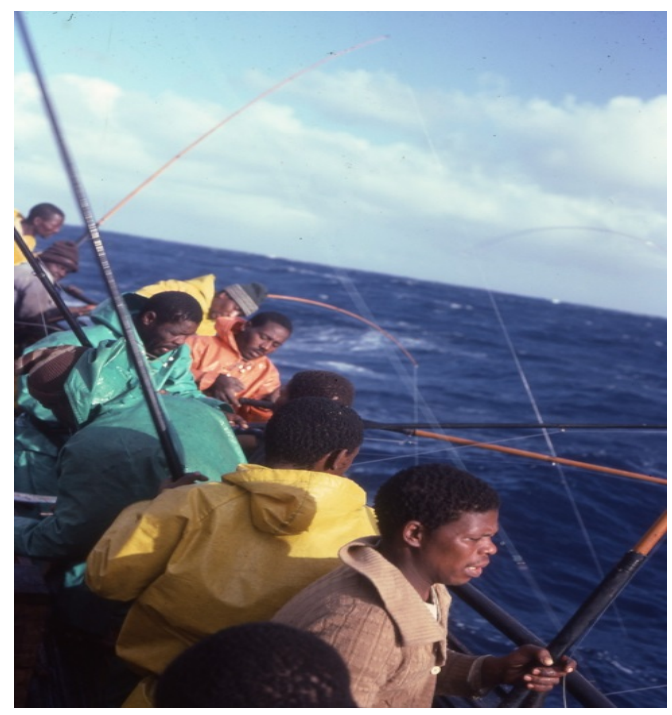

Figure 3. Typical fishing scene at Bassas.

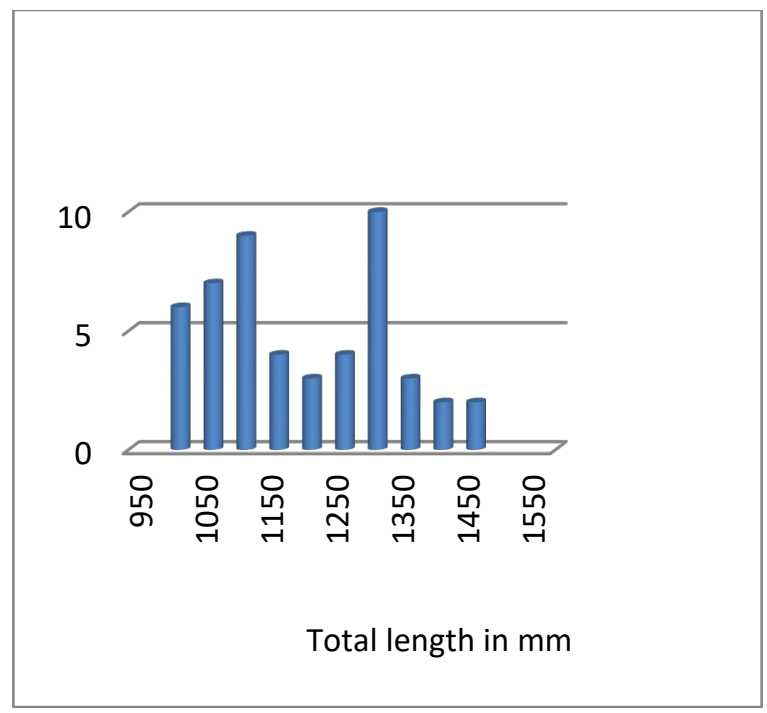

Figure 4. Length frequency distribution (mm total length) of a sample of Epinephelus tukula $(\mathrm{n}=50)$ caught by commercial linefishers at Bassas da India and Europa Islands in 1985 over a week of linefishing.

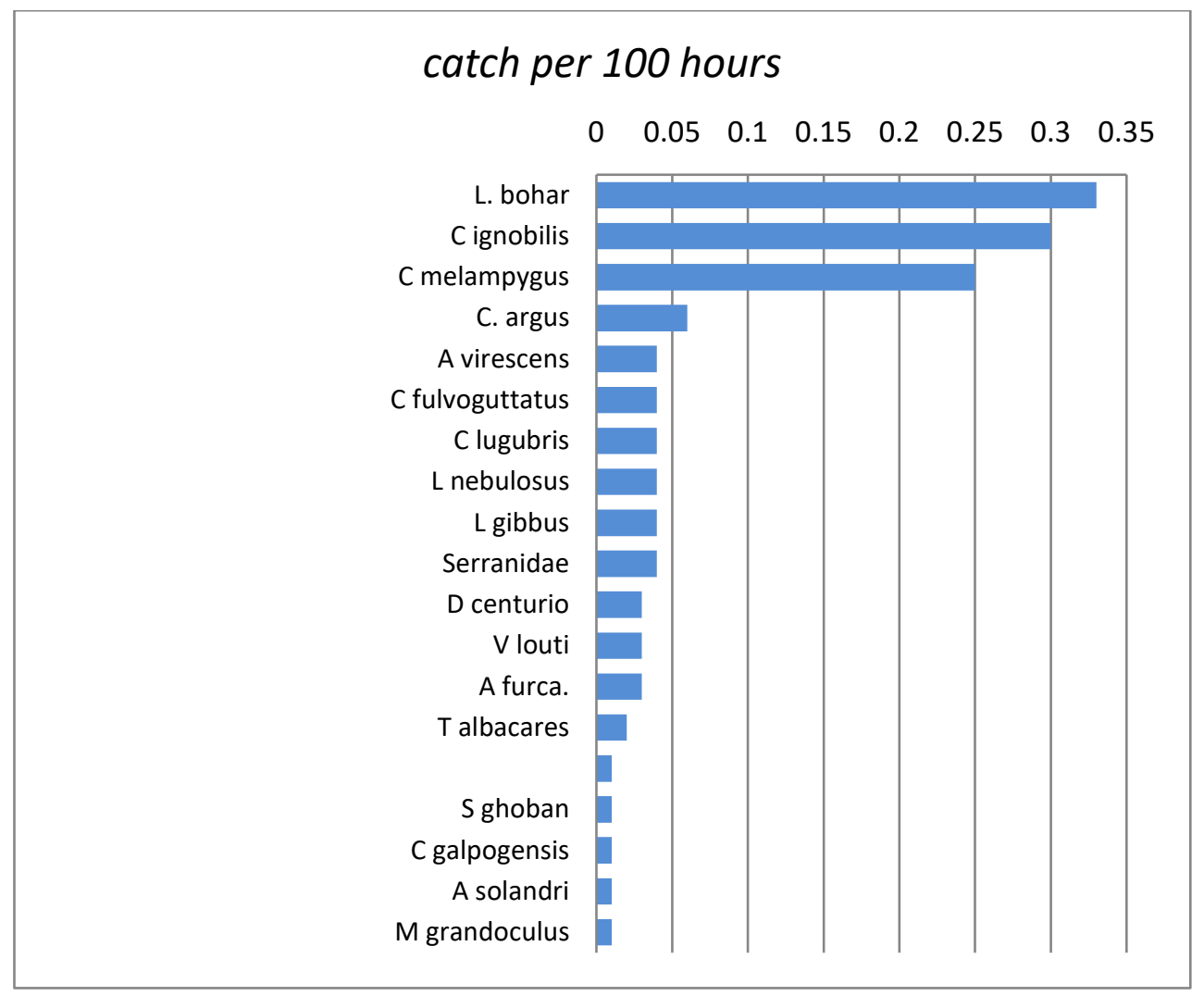

Figure 5. Catch rates of fish species caught by research angling at Bassas da India in July 1991. 
Table 5. Details of linefish catch rates for two groups of anglers conducting research fishing at Bassas da India in July 1991

\begin{tabular}{|l|c|c|}
\hline Indicator & Group A & Group B \\
\hline Total angling hours & 122.1 & 24 \\
\hline Total number of fish caught & 149 & 72 \\
\hline Total weight of catch $(\mathrm{kg})$ & 880 & 226 \\
\hline Overall CPUE (fish per hour) & 1.22 & 3.0 \\
\hline Number of species caught & 20 & 7 \\
\hline Weight per hour (kg) & 6.3 & 9.4 \\
\hline
\end{tabular}

Clearly, these are very high catch rates and indications are that similarly high rates may be obtained by tourist charter operators that fish in the area.

\section{Conservation Status of the Fishes}

While there has been very little exploitation at Bassas, and there is also no development of any kind, it follows that the ichthyofauna should mostly reflect a near-pristine or baseline situation. However, the periodic linefishing excursions that remove a high proportion of the large groupers are likely to have a cascade effect on the remaining species. The 309 species reflect a seemingly stable environment which, if monitored, can serve as a benchmark into the future. In order to create such a benchmark, each of the species recorded has been rated with the 2020 IUCN Red List vulnerability index (see Appendix 1). The overall breakdown of Red List status of the Bassas ichthyofauna is shown in Figure 6.

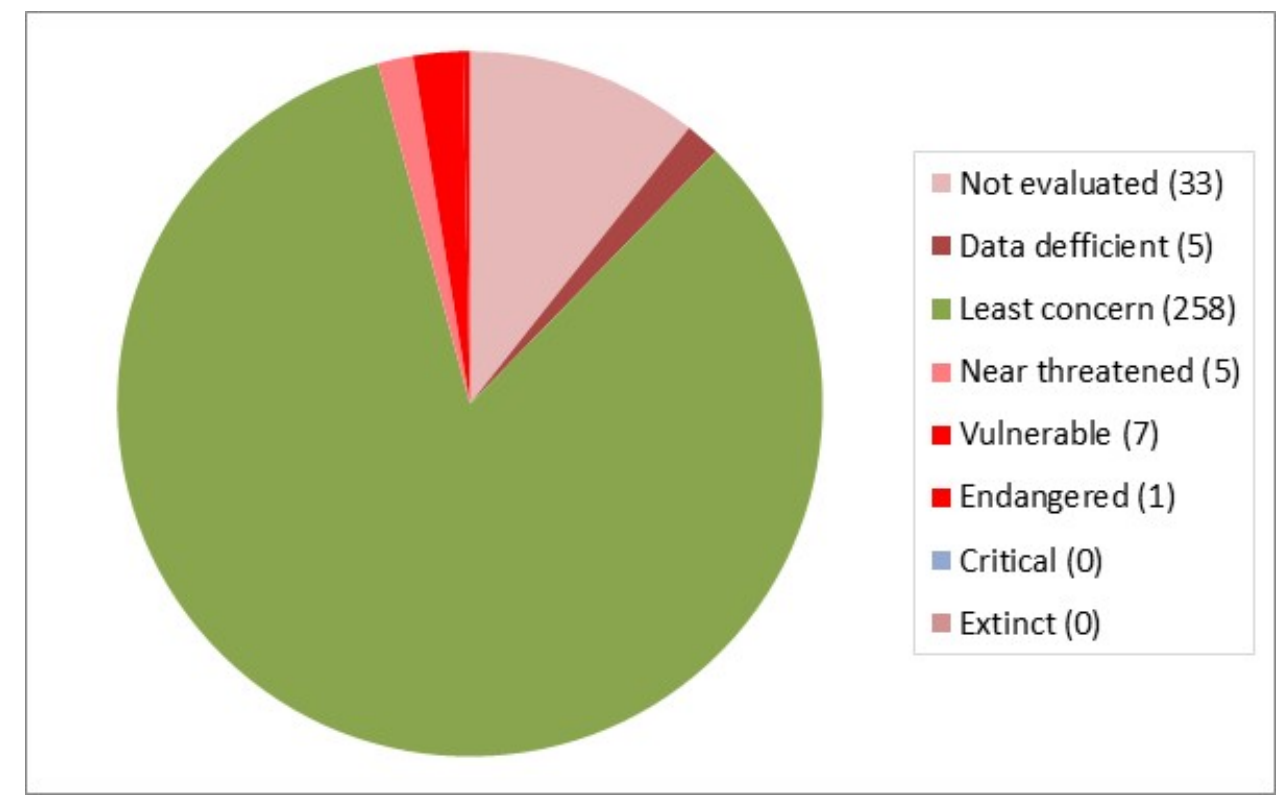

Figure 6. IUCN Red List status of 309 fish species documented at Bassas da India. 


\section{DISCUSSION}

With accelerating climate change, the task of monitoring biodiversity hotspots on small atolls has become urgent, especially considering the limited sites where vulnerable and endangered species still occur in numbers and as part of an undisturbed ecosystem. Aside from human impacts such as fishing, global warming has already posed a major threat to reef ecology, especially in the tropics. In most cases where ocean warming has resulted in bleaching of corals, changes in the diversity of fishes can also be expected. Chabanet (2002) demonstrated that the 1998 warming event in Mayotte caused considerable coral bleaching which in turn stimulated algal growth on the dead corals, effectively altering the substrate biota. This in turn favoured the herbivorous surgeonfishes, while the butterflyfishes were left without their source of live coral. Similar results were published by Garpe et al. (2006), who related bleaching impacts in Tanzania, highlighting the short term [6 months] effect with increased herbivores followed by a much longer and serious secondary effect on structure of the entire fish community.

Tracking changes in ichthyofauna, either over time or between different sites can be a useful tool in tracking or predicting the impacts of climate change. But, as demonstrated here between the atolls of Bassas da India and Europa, comparing diversity based on families only can be misleading if actual species are not considered. Indeed, certain species can thus also be used a bio-indicators, which can be applied to various localities.

The reasons for the different species composition between Bassas and Europa can be attributed to a number of possible causes. For one, species normally associated with estuarine habitats (Therapon sp., Rhabdosargus sarba, Bothus mancus, Monodactylus sp., and Albula sp.) were recorded at Europa but not on Bassas da India, despite the fact that these species are exceptionally well represented to the east and west in the SW Indian Ocean generally including Europa (Comeros-Raynal et al., 2016). However, these species are often associated with nutrient-rich substrates, which are lacking on Bassas, while Europa has a stand of mangroves and a richer substrate, probably attributable to the great quantity of nutrients brought in by the million or more sooty terns that nest annually on Europa. Their guano must surely assist the growth of mangroves and other terrestrial vegetation.

Several authors have demonstrated changing trends in ichthyofauna associated with climatic events and especially following coral bleaching. Chabanet (2002) demonstrated changes in fish communities at the island of Mayotte, with shifts in the relative abundance of herbivores and browsers two years after the 1998 bleaching event. This was almost certainly related to coral mortality and loss of a food source for coral browsing species. In the case of Bassas da India there is no decades-long sequence of data that could reveal trends in ichthyofauna, but changes linked to climate change can reasonably be expected.

Although the extent and methodology of fish collecting at Bassas da India was preliminary, it points to a considerable diversity of fishes which is broadly similar to that reported from Geyser Reef by Chabanet et al. (1996). While these figures are approximations, it is interesting to note that herbivores are of lower diversity at these more oceanic islands, both of which are fully inundated at high tide. In contrast, regions closer to the continental coast have a much higher diversity of plant-eating species. The reasons for this are at hand when one considers that neither Bassas da India nor Geyser have obvious stands of seaweed or seagrass. Indeed, any future climate change induced mortalities of corals is likely to be detected in the trophic composition of the ichthyofauna should plants (especially algae) replace corals. While not likely in the oligotrophic waters of these offshore atolls, should nutrients be made available, for example via pollution, algae may bloom, creating a eutrophic environment detrimental to coral symbiosis.

All the 40 species reported by Fourmanoir (1952) were also reported by Fricke et al. (2013) from Europa Island. Chabanet et al. (1996) reported on the ichthyofauna of Geyser Reef and Zeelie Bank, with their records of 297 species reflecting a 95\% similarity with the species recorded from Bassas da India during this survey. The Bazaruto Archipelago, which lies on the Mozambique coast at approximately the same latitude as Bassas, also has considerable coral reef habitat in addition to other ecosystems. A total of 306 species was reported by van der Elst and Afonso (2009) based on more frequent sampling over a 25 -year period, very similar to the 309 species recorded for Bassas over the more intensely sampled but shorter period.

These oceanic sites are also reservoirs of biodiversity that can contribute to recruitment patterns of species overexploited in other regions. In his analysis of current systems in the South West Indian Ocean, 
Lutjeharms (2006) suggests that the Mozambique and East Madagascar boundary currents are not always well defined and predictable. The waters surrounding Bassas da India are impacted by two current systems which generate periodic cyclonic eddies moving down the Mozambique Channel in a south-westerly direction (Lutjeharms, 2006). These in turn may lead to more homogeneous or well-mixed water masses, which are more conducive to a stable ichthyofauna, and which strengthen the potential role of these atolls in contributing to the region's larval fish population. The fact that Bassas da India has seemingly healthy populations of endangered species, such as the humphead wrasse and several large serranid species, is especially important and justifies the atoll's no-take protected status. The dominance of apex predators at all sites is noteworthy, as is their low abundance reported for Bassas and Geyser Reef (Chabanet et al., 1996). Many of the species that make up the carnivore component are apex predators, often of large size and dominance. Examples include the large Serranidae, Lutjanidae, Sphyraenidae and Carangidae. In particular the presence of giant grouper is believed to exercise dominant 'control' and outcompete sharks. The fact that these species appear to be more dominant on the offshore islands that are difficult to reach is almost certainly attributable to the lower fishing effort that is exerted there, hence the trophic structure and associated biodiversity is likely to be closer to a 'natural' state where little or no human-induced fishing mortality occurs. Further study of this concept is needed as it raises a number of important questions with respect to species dominance on coral reefs. Moreover, what influence could fisheries have if a dominant group is removed (Mourier et al., 2016)?

The catch rates of 1.22 and 3 fish per hour recorded here are very high by most standards, except in cases where the fishing takes place in a fully protected environment, such as within the iSimangaliso Wetland Park (South Africa), where Mann (2019) reported rates of 1.41 fish per hour under similar circumstances as seen here. An estimate of catches taken by the recreational charter operators at Bassas was calculated by Le Manach and Pauly (2015). While this provides a start, our experiences did not entirely concur with these estimates. We find that their postulated 20 charter trips, each for six times per year, was excessive and is likely no more than $1 / 2$ of that. The proposed estimated catch of $500 \mathrm{~kg}$ per trip may not be unrealistic if the high catch rates recorded during our survey are considered. However, this would depend on the number of anglers, the number of days and hours fished. Also, freezer capacity on such charter yachts is very modest and the fact that most operations release at least some of their catch, the $500 \mathrm{~kg}$ would not be the actual fishing mortality. Moreover, the species composition proposed by Le Manach and Pauly (2015) are not entirely in line with our data and biodiversity of the atoll. Nevertheless, these records may in time play an important role in benchmarking changes in the biodiversity of the atoll.

While the lack of human settlement at Bassas da India will have contributed to the conservation of fishes there, this also means that uncontrolled exploitation can occur surreptitiously. As reported here, periodic visits by fishing boats, tourist yachts and spearfishing groups are known to have harvested fish surrounding Bassas da India. Considering that some of these species have relatively slow growth rates and that the age of many will have been in excess of 30 years, the impact of this targeted removal of the top predators is likely to manifest itself in any future biodiversity assessment of the atoll. Furthermore, the targeting of these apex large predators by pulse fishing may also lead to a gender imbalance and compromise future offspring as many of these species are protogynous hermaphrodites so that many more larger males will be removed.

Other intrusions have been reliably reported, including naval exercises using mortars, physical damage to the reefs in search of ship artefacts and a number of shipping accidents with associated pollution and damage to the atoll ecosystem. Although current angling charter operators' websites claim their operations to be environmentally sensitive, their ignorance in this regard is apparent when promoting activities such as: "On arrival, throw anchor and then...take a walk on the rocks where old shipwrecks can be explored and interesting marine life can be seen in the rock pools (remember your sandals to protect your feet!)." There are no rocks - only ultra-vulnerable corals!

Notwithstanding the relatively stable global fisheries catch in the WIO over time (van der Elst, 2015), a number of individual populations appear to be increasingly vulnerable. In view of the high and growing dependence on fisheries in the WIO (van der Elst et al., 2005), the protection of small island ecosystems and their fish populations may take on a greater significance in the future, especially as refuges for spawning stock and incubators of new recruits to the region. Considering the ease with which fish can be depleted at such small island sites, it is incumbent on the authorities to ensure that strict surveillance and protection is in 
place. In turn, this calls for strong regional collaboration through the Nairobi Convention, the FAO regional office and similar structures.

The importance of protecting the 59 marine biodiversity hotspots in the WIO cannot be overstated (Everett and van der Elst, 2015). As the more accessible coastal resources become depleted or impacted through climate change, so fishers will venture further afield, especially attracted by historically protected areas, where a large 'once-off' catch can be made. Clearly this happened at Bassas, with the periodic visits by linefishing boats which impacted a significant number of fishes, especially slow-growing red-listed species. This paper highlights the vulnerability of hotspots like Bassas and raises concern about their protection. Indeed, the conservation status of Bassas da India lies only in its proclamation as a nature reserve and periodic regulations pertaining to fishing. This appears inadequate, accentuated by the contested nature of ownership of this and the other Eparses islands. Only Glorieuses appears to have been formally proclaimed as a no-take marine protected area (MPA) (République Française, 2012).

We hereby make a strong plea for the establishment of a multinational 'Forum of WIO Biodiversity Hotspots,' under the aegis of the Nairobi Convention. The regional need of their protection is further emphasised by the contested ownership of several of these hotspots. A common regional vision and commitment towards the significant protection of these biodiversity reservoirs may well prove to be a critical tool to mitigate against climate change.

\section{CONCLUSION}

This study has shown that species surveys can be a useful tool in detecting possible environmental changes brought about by climate change. However, care should be taken when using only the number of families as a basis for such assessments, as in the case of trophic comparisons. For example, the differences in species composition between Bassas and Europa atolls were substantial, even though their family composition appeared similar. The reason for these differences can be one or more of the following:

- The three decades interval between surveys, suggests that climate change may already playing a role by altering the habitat and thus the species composition.

- The level of work and methodology may be dissimilar

- The ecosystems are different between the two atolls. Europa has dry land and wetlands.

- Europa is larger than Bassas

It is clear that groupers and sharks are apex predators that compete for space. A stable population appears to be when large groupers dominate. Removal of the groupers through fishing can lead to an increase in shark activity. This further highlights the importance of protecting these small atolls against fishing and should be recognised as no-take reserves. It is suggested that both Bassas and Europa are considered reference sites, subjected to decadal surveys. Based on these conclusions it considered important to repeat both surveys in order to establish the root causes for the species differences.

\section{ACKNOWLEDGEMENTS}

We dedicate this paper to the memory of Jack Randall, who provided enthusiastic support to this project. Good work by the survey team is acknowledged, viz. John Ballard (Sea World), Alan Connell (CSIR), Phil van der Elst (Engineer), Geremy Cliff (Sharks Board), Paul Descoin (Medical) and Dez Willens (Captain). Assistance with species identification was gratefully received from Dr R. Winterbottom (Royal Ontario Museum), Dr P. Heemstra (South African Institute for Aquatic Biodiversity), Dr J. Olney (Virginia Institute of Marine Science), Dr J. Randall (Bishop Museum), Dr K. Carpenter (Fishery Resources \& Environment Division, FAO), Dr L. Compagno (Iziko South Africa Museum, Cape Town) and Dr R. Mooi (Milwaukee Public Museum). Bernadine Everett (ORI) is thanked for commenting on the text and in preparing the fine map. Maxime Amy, Coordinateur des programmes de conservation des Iles Eparses (Reunion) is thanked 
for his support and interest. The insightful comments from the editor and two referees are much appreciated.

\section{REFERENCES}

Allen G.R., and Steene R.C. 1987. Reef Fishes of the Indian Ocean. TFH Publications, Brookvale, Australia. $240 \mathrm{pp}$.

Anderson, A.B., Bonaldo, R.M., Barneche, D.R., Hackradt, C.W., Félix-Hackradt, F.C., García-Charton, J.A., Floeter, S.R. 2014. Recovery of Grouper Assemblages Indicates Effectiveness of a Marine Protected Area in Southern Brazil. Marine Ecology Progress Series 514: 207-215.

Braithwaite, C.J.R. 1984. Geology of the Seychelles. In Stoddardt, D.R. (ed.), Biogeography and Ecology of the Seychelles Islands. W Junk, The Hague: 17-38.

Burgess, W.E., Axelrod, H.R., and Hunziker, R.E. 1990. Dr Burgess's Atlas of Marine Aquarium fishes. TFH Publications, Neptune City. 768 pp.

Burke, L., Reytar, R., Spalding M., Perry, A. 2011. Reefs at Risk Revisited 2011. World Resources Institute. Library of Congress Control Number: 2011922172. ISBN 978-1-56973-762-0.

Chabanet, P., Tessier, E., Poisson, F., Rene, F. 1996. Diagnostic sure l'etat de la Ressource en Poissons des Banc de Geyser et Zelee. Collectivite territoriale de Mayotte. IFREMER - La Réunion, p. 54.

Chabanet, P. 2002. Coral Reef Fish Communities of Mayotte (Western Indian Ocean) Two Years after the Impact of the 1998 Bleaching Event. Marine and Freshwater Research 53:107-113.

Chabanet, P., and Durville, P. 2005. Reef Fish Inventory of Juan de Nova's Natural Park (Western Indian Ocean). Western Indian Ocean Journal of Marine Science 4: 145-182.

Chater, S.A., Beckley, L.E., Garratt, P.A., Ballard, J.A., van der Elst, R.P. 1993. Fishes from Offshore Reefs in the St Lucia and Maputaland Marine Reserves, South Africa. Lammergeyer 42:1-17.

Comeros-Raynal, M.T., Polidoro, B.A., Broatch, J., Mann, B.Q., Gorman, C.E., Buxton, C.D., Goodpaster, A.M., Iwatsuki, Y., MacDonald, T.C., Pollard, D., Russell, B., Carpenter, K.E. 2016. Key Predictors of Extinction Risk in Sea Breams and Porgies (Family: Sparidae). Biological Conservation 202: 88-98.

Compagno, L.J.V. 1984a. Sharks of the World: An Annotated and Illustrated Catalogue of Shark Species known to Date. Part 1. Hexanchiformes to Lamniformes. FAO Fisheries Synopsis 125 (4):1-249.

Compagno, L.J.V. 1984b. Sharks of the World: An Annotated and Illustrated Catalogue of Sharks Species Known to Date. Part 2. Carcharhiniformes. FAO Fisheries Synopsis 124 (4):251-655.

Courgeon, S., Jorry, S.J., Jouet, G., Camoin, G., BouDagher-Fadel, M.K., Bachèlery, P., Caline,, B., Boichard R., Révillon, S., Thomas, Y., Thereau, E., Guérin, C. 2017. Impact of tectonic and volcanism on the Neogene evolution of isolated carbonate platforms (SW Indian Ocean). Sedimentary Geology 355: 114-131. https://doi.org/10.1016/j.sedgeo.2017.04.008

Cousteau, J-Y. 1966-1976. The Undersea World of Jacques Cousteau. Film IMDb, Paris.

Domeier, M. 2016. Extreme Inverted Trophic Pyramid of Reef Sharks Supported by Spawning Groupers. Current Biology 26:2011-2016.

Duce, $_{2}$ S., Concejo ${ }_{2}$ A.V., Hamylton, S., Bruce, E., Webster, J.M. 2014. Spur and Groove Distribution, Morphology and Relationship to Relative Wave Exposure, Southern Great Barrier Reef, Australia. Journal of Coastal Research 70:115-120.

Everett, B.L., and van der Elst, R.P. 2015. Biodiversity Hotspots of the Southwest Indian Ocean: Their Location and Primary Features. In van der Elst, R.P., and Everett, B.I. (eds.), Offshore Fisheries of the Southwest Indian Ocean: Their Status and the Impact on Vulnerable Species. Oceanographic Research Institute, Special Publication. 448 pp.

Fischer, W., and Bianchi, G. 1984. FAO Species Identification Sheets for Fishery Purposes. Western Indian Ocean (Fishing Area 51). Vols. 1-4. FAO, United Nations, Rome.

Fourmanoir, P. 1952. Observations sur la Faune Marine et la Peche a l'ile Europa. Memoirs of the Institute of Science of Madagascar Series A 7(2):167-188.

Atoll Research Bulletin, No. 629 
Fricke, R., Durville, P., Bernardi, G., Borsa, P., Mou-Tham, G., Chabanet, P. 2013. Checklist of the Shore Fishes of Europa Island, Mozambique Channel, Southwestern Indian Ocean, Including 302 New Records. Stuttgarter Beiträge zur Naturkunde A, Neue Serie, (6):247-276.

Frisch, A.J., Ireland, M., Rizzari, J.R., Lönnstedt, O.M., and Hobbs J.-P. 2016. Reassessing the Trophic Role of Reef Sharks as Apex Predators on Coral Reefs. Coral Reefs 35:459-472.

Glynn, P.W. 1984. Coral Reefs and Recent Disturbances: Cause for concern? (Abstract). Advances in Reef Science, a joint meeting of the Atlantic Reef Committee, Rosenstiel School of Marine and Atmospheric Science, Univ. of Miami and The International Society for Reef Studies, Miami, October 1984.

Han, G., Dong, C., Li, J., Yang, J., Wang, Q., Liu, Y., Sommeria, J. 2019. SST Anomalies in the Mozambique Channel Using Remote Sensing and Numerical Modeling Data, School of Marine Science, Nanjing University of Information Science and Technology, Nanjing, China. Remote Sensing 11:1112.

Harroy, J.P. 1972 Addendum and corrigendum to 2nd Ed. of UN List of National Parks and Equivalent Protected Areas. Hayez, Brussels.

Heemstra, P.C., Randall, J.E. 1993. FAO species catalogue, Vol. 16. Groupers of the world (Family Serranidae, Subfamily Epinephelinae). FAO Fisheries Synopsis, 125, FAO, Rome.

IOTC 2020. Stock Status for Species of Tuna and Tuna-like Fisheries Under the IOTC Mandate as Well as other Species Impacted by OITC Fisheries. Scientific Reports: Annual General Meeting.

Garpe, K.C., Yahya, S.A.S., Lindahl, U., Öhman, M.C. 2006. Long-term Effects of the 1998 Coral Bleaching Event on Reef Fish Assemblages. Marine Ecology Progress Series 315:237-247.

Le Manach, F., Pauly, D. 2015. Fisheries Catch Reconstructions: First estimate of unreported catch in the French Isles Eparses: 1950-2010. Fisheries Centre, University of British Columbia, Vancouver. 36 pp.

Lutjeharms J.R.E. 2006. The Agulhas Current. Springer Verlag, Berlin. 329 pp.

Maina, J. Venus, V. McClanahan, T., Ateweberhan, N. 2008. Modelling susceptibility of coral reefs to environmental stress using remote sensing data and GIS models. Ecological Modelling 212:180-199.

Mann, B.Q. 2016. An assessment of the effectiveness of the St Lucia Marine Reserve (KZN), South Africa, in the protection of surf-zone angling fish species. PhD thesis. University of KwaZulu-Natal. $136 \mathrm{pp}$.

Masuda, H., Amaoka, K., Araga, C., Uyeno, T., Yoshino, T. 1984. The fishes of the Japanese Archipelago. Tokai University Press, Tokyo. 437 pp., 370 plates.

Mourier, J., Maynard, J., Planes, S. 2016. Extreme Inverted trophic pyramid f reef sharks supported by spawning groupers. Current Biology 26:2011-2016.

Nelson, J. F., Grande, T.C., Wilson. M.V.F. 2016. Fishes of the World, 5th Edition. 752 pp. Wiley, New York.

Obura, D., Suleiman, M., Motta, H., Schleyer, M. 2000. Status of Coral Reefs in East Africa: Kenya, Mozambique, South Africa and Tanzania. In: Wilkinson, C. (ed.). 2000. Status of Coral Reefs of the World. CCRM. Australian Institute of Marine Science. 363 pp.

Obura, D. 2015. Corals and biogenic reefs 71-82. In: UNEP-Nairobi Convention and WIOMSA (2015). The Regional State of the Coast Report: Western Indian Ocean. UNEP and WIOMSA, Nairobi, Kenya, 65-76.

Oraison, A. 2015. Réflexions Critiques sur l'accord-cadre Fanranco-Maritiauricien du 7 juin 2010 Ratif à la cogestion économique, scientifique et environnementale du Fécif de Tromelin et de ses espaces maritimes environnants. Revue juridique de l'Océan Indien, Association "Droit dans l'Océan Indien" (LexOI), 2015, pp. 129-168. ffhal-02547856f.

Pfeiffer, M., Zinke, J., Dullo, C., Garbe-Schönberg, D., Latif, D.M., Weber, M.E. 2017. Indian Ocean corals reveal crucial role of World War II bias for twentieth century warming estimates. Scientific Reports 31:14434. https://doi.org/10.1038/s41598-017-14352-6

Randall, J.E. 1977. Contribution to the biology of the whitetip reef shark (Triaenodon obesus). Pacific Science 31(2):143-164.

Randall, J.E. 1998. Zoogeography of shore fishes of the Indo-Pacific region. Zoological Studies 37:227-268.

Randall, J.E., Heemstra P.C. 1991. Revision of Indo-Pacific groupers (Perciformes: Serranidae: Epinephalinae), with descriptions of five new species. Indo-Pacific Fishes 20:1-332. 
République Française, 1975. Arrêté préféctoral n 13/DG/IOI du 18 novembre 1975.

République Française, 1978. Décret n 78-146 du 3 février 1978 Portant Création, en Application de la loi du 16 juillet 1976, d'une Zone Economique au large des Côtes des Iles Tromelin, Glorieuses, Juande-Nova, Europa et Bassas da-India. Journal Offciel de la République Française, 686-686

République Française, 2012. Décret n 2012-245 du 22 février 2012 Portant Création du Parc Naturel Marin des Glorieuses. Journal Offciel des Terres Australes et Antarctiques Françaises, 53:21-23.

Smith, M.M., Heemstra, P.C 1986 (and 1991 errata). Smith's Sea Fishes. Macmillan, Johannesburg. 1047 pp.

Stuckenberg, B.R. 2000. The location and identity of the Baixos da Judia: Portuguese historical cartography of the Mozambique Channel and its relevance to the wreck of the Santiago in 1585. Natal Museum Journal of Humanities Vol 1:51-78.

van der Elst, R.P., Everett, B., Jiddawi, N., Mwatha, G., Boulle, D. 2005. Fish, Fishers and Fisheries of the Western Indian Ocean: their Diversity and Status. A Preliminary Assessment. Philosophical Transactions of the Royal Society A.363263-284.

van der Elst, R.P. and Afonso, P.S. 2009. The Fishes of Bazaruto. In Everett, B.F, van der Elst, R.P., and Schleyer, M.S. (eds.), The Natural History of the Bazaruto Archipelago. Special Publication. Oceanographic Research Institute, Durban: Chapter 10:74-87.

van der Elst, R.P. 2015. Conclusion. In van der Elst, R.P. and Everett, B.I. (eds.), Offshore Fisheries of the Southwest Indian Ocean: Their Status and the Impact on Vulnerable Species. Special Publication, Oceanographic Research Institute, pp 441-443.

Winterbottom, R., Emery, A.R., Holm, E. 1989. An Annotated Checklist of the Fishes of the Chagos Archipelago Central Indian Ocean. Life Sciences Contributions 145. Royal Ontario Museum.

Wilkinson, C. (ed.). 2000. Status of Coral Reefs of the World: 2000. Global Coral Reef Monitoring Network, Australian Institute of Marine Science, Queensland.

Zinke, J., D'Olivo, J.P., Gey, C.J., McCulloch, M.T., Bruggemann, J.H., Lough, J.M., Guillaume, M.M. 2019. Multi-trace-element Sea Surface Temperature Coral Reconstruction for the Southern Mozambique Channel Reveals Teleconnections with the tropical Atlantic. Biogeosciences 16:695712. https://doi.org/10.5194/bg-16-695-2019 


\section{APPENDIX 1: CHECKLIST OF FISHES FROM BASSAS DA INDIA}

\section{Systematically arranged according to Nelson et al. (2016)}

A combined table of species recorded either as a captured specimen (S), by capture and release (C), visual observation (V) confirmed by two or more experts and/or as a photo record (P). Locality, main region of Western Indian Ocean includes Mauritius, Seychelles, Red Sea, Comoros and the Chagos Archipelago.

Distribution and IUCN Red List status in 2020 is given: Vulnerable VU, Near Threatened NT, Data Deficient DD, Least Concern LC, Not Evaluated NE. The most threatened groups are in red. Note that taxonomy is applied at the earlier dates, pre-2005, so as to be consistent with historic records. For example, the family Epinephalidae is not applied here and remains Serranidae.

\begin{tabular}{|c|c|c|c|c|}
\hline Family and Species & Method & Habitat Notes & $\begin{array}{l}\text { Specimen Size } \\
\quad(\mathrm{mm})\end{array}$ & $\begin{array}{l}\text { IUCN } \\
\text { Red } \\
\text { List }\end{array}$ \\
\hline CARCHARHINIDAE & & GREY SHARKS & 6 & \\
\hline $\begin{array}{l}\text { Carcharhinus } \\
\text { albimarginatus (Ruppell, } \\
\text { 1837) }\end{array}$ & $\mathrm{P}$ & $\begin{array}{l}\text { Seen on the drop-off, singly or in loose } \\
\text { packs; excitable when fish were speared in } \\
\text { their proximity. Common. Indo-Pacific. }\end{array}$ & Adult & $\mathbf{V U}$ \\
\hline $\begin{array}{l}\text { Carcharhinus altimus } \\
\text { (Springer, 1950) }\end{array}$ & $\mathrm{V} \& \mathrm{P}$ & $\begin{array}{l}\text { A single large specimen seen on two } \\
\text { separate occasions in } 1-2 \mathrm{~m} \text { across the reef } \\
\text { top. Circumtropical }\end{array}$ & Adult & DD \\
\hline $\begin{array}{l}\text { Carcharhinus } \\
\text { galapagensis (Snodgrass } \\
\text { \& Heller, 1905) }\end{array}$ & $\mathrm{V} \& \mathrm{C}$ & $\begin{array}{l}\text { Common: Indo-Pacific. Several seen at } \\
\text { night outside the reef. }\end{array}$ & $1400 \mathrm{TL}$ & NT \\
\hline $\begin{array}{l}\text { Carcharhinus } \\
\text { amblyrhynchos (Garrick, } \\
\text { 1982) }\end{array}$ & $\mathrm{V}$ & $\begin{array}{l}\text { Several individuals seen on the drop- off. } \\
\text { Western Indian Ocean. }\end{array}$ & Adult & NT \\
\hline $\begin{array}{l}\text { Carcharhinus } \\
\text { melanopterus (Quoy \& } \\
\text { Gaimard, 1824) }\end{array}$ & $\mathrm{V}$ & $\begin{array}{l}\text { Single specimen recorded from the lagoon. } \\
\text { Indo-Pacific. }\end{array}$ & $900 \mathrm{TL}$ & NT \\
\hline $\begin{array}{l}\text { Galeocerdo cuvieri } \\
\text { (Peron \& Lesueur, 1822) }\end{array}$ & $\mathrm{C}$ & $\begin{array}{l}\text { One, captured on a baited line in the } \\
\text { lagoon. Tagged (SFW-ORI tag no. B } \\
\text { 010438) and released. Circumtropical. }\end{array}$ & $1500 \mathrm{TL}$ & NT \\
\hline MYLIOBATIDAE & & EAGLE RAYS & & \\
\hline $\begin{array}{l}\text { Aetobatus ocellatus } \\
\text { (Euphrasen, 1790) }\end{array}$ & $\mathrm{P}$ & $\begin{array}{l}\text { Recorded from the drop-off. } \\
\text { Circumtropical. }\end{array}$ & Adult & $\mathbf{V U}$ \\
\hline MOBULIDAE & & MANTAS & & \\
\hline $\begin{array}{l}\text { Manta (Mobula) birostris } \\
\text { (Donndorff, 1798) }\end{array}$ & $\mathrm{V}$ & $\begin{array}{l}\text { Several large individuals seen outside the } \\
\text { entrance channel to the atoll. } \\
\text { Circumtropical. }\end{array}$ & Adult & $\mathbf{V U}$ \\
\hline DASYATIDAE & & STINGRAYS & & \\
\hline Himantura marginata? & $P \& S$ & $\begin{array}{l}\text { One specimen collected from the lagoon by } \\
\text { spear. Species unknown (new?) tentatively } \\
\text { identified as Himantura marginata by L. } \\
\text { Compagno. Several similar rays were seen } \\
\text { in shallow water on the sandbar near the } \\
\text { entrance channel to the lagoon. The } \\
\text { specimen is housed at the S.A. Museum in } \\
\text { Cape Town. }\end{array}$ & ? DW & DD \\
\hline
\end{tabular}




\begin{tabular}{|c|c|c|c|c|}
\hline MURAENIDAE & & MORAYS & & \\
\hline $\begin{array}{l}\text { Gymnothorax javanicus } \\
\text { (Bleeker, 1859) }\end{array}$ & $\mathrm{P}$ & $\begin{array}{l}\text { Common on coral bommies in the lagoon } \\
\text { and the drop-off. Indo-West Pacific. }\end{array}$ & & $\mathrm{LC}$ \\
\hline $\begin{array}{l}\text { Gymnothorax buroensis } \\
\text { (Bleeker, 1857) }\end{array}$ & $\mathrm{P} \& S$ & Reef-top. Indo-Pacific. & $215 \mathrm{TL}$ & $\mathrm{LC}$ \\
\hline $\begin{array}{l}\text { Gymnothorax ruepelliae } \\
\text { (McClelland, 1845) }\end{array}$ & $\mathrm{P} \& \mathrm{~S}$ & Reef-top. Indo-Pacific. & $151 \mathrm{TL}$ & $\mathrm{LC}$ \\
\hline $\begin{array}{l}\text { Gymnothorax undulatus } \\
\text { (elaineheemstrae)? } \\
\text { (Lacepede, 1803) }\end{array}$ & $\mathrm{S}$ & $\begin{array}{l}\text { One specimen sampled. Reef-top. Indo- } \\
\text { Pacific. }\end{array}$ & $198 \mathrm{TL}$ & $\mathrm{LC}$ \\
\hline CLUPEIDAE & & SARDINES & & \\
\hline $\begin{array}{l}\text { Spratelloides delicatulus } \\
\text { (Bennett, 1831) }\end{array}$ & $\mathrm{S}$ & $\begin{array}{l}\text { Dense shoals were seen over the shallow } \\
\text { sandbanks in the Lagoon near the entrance } \\
\text { channel. Indo-Pacific. }\end{array}$ & $\begin{array}{l}45 \text { specimens: } \\
\text { 40-45 TL }\end{array}$ & $\mathrm{LC}$ \\
\hline CHANIDAE & & MILKFISH & & \\
\hline $\begin{array}{l}\text { Chanos chanos (Forskall, } \\
\text { 1785) }\end{array}$ & $\mathrm{V}$ & $\begin{array}{l}\text { Several large individuals seen swimming } \\
\text { over the reef-top at high tide. Indo-West } \\
\text { Pacific. }\end{array}$ & Adult & $\mathrm{LC}$ \\
\hline SYNODONTIDAE & & LIZARDFISHES & & \\
\hline $\begin{array}{l}\text { Saurida gracilis (Quoy \& } \\
\text { Gaimard, 1824) }\end{array}$ & $\mathrm{P} / \mathrm{S}$ & Lagoon. Indo-west Pacific & $145 ; 205 \mathrm{FL}$ & $\mathrm{LC}$ \\
\hline $\begin{array}{l}\text { Synodus binotatus } \\
\text { Schultz, } 1953\end{array}$ & $\mathrm{P} / \mathrm{S}$ & Lagoon. Indo-west Pacific & $\begin{array}{l}105 ; 80 ; 80 ; 72 \\
\text { FL }\end{array}$ & $\mathrm{LC}$ \\
\hline $\begin{array}{l}\text { Synodus dermatogenys } \\
\text { Fowler, } 1912\end{array}$ & $\mathrm{~V}$ & $\begin{array}{l}\text { Common throughout the lagoon over sand } \\
\text { near bommies. Indo-West Pacific. }\end{array}$ & & $\mathrm{LC}$ \\
\hline CARAPIDAE & & $\begin{array}{l}\text { PEARLFISHES (All pearlfish specimens } \\
\text { were identified by Dr John Olney, Virginia } \\
\text { Institute of Marine Science.) }\end{array}$ & & \\
\hline $\begin{array}{l}\text { Encheliophis homei } \\
\text { (Richardson, 1844) }\end{array}$ & $\mathrm{S}$ & $\begin{array}{l}\text { Taken from the holothurian Bohadschia } \\
\text { argus in the lagoon. Circumtropical. RUSI } \\
\text { No:044310 }\end{array}$ & 4 specimens & $\mathrm{NE}$ \\
\hline $\begin{array}{l}\text { Encheliophis } \\
\text { boraborensis (Kaup ?) }\end{array}$ & $\mathrm{S}$ & $\begin{array}{l}\text { All collected from specimens of the } \\
\text { holothurian Thelanota anax in the lagoon. } \\
\text { Indo-Pacific. RUSI No:044312 }\end{array}$ & 4 specimens & $\mathrm{NE}$ \\
\hline $\begin{array}{l}\text { Encheliophis gracilis } \\
\text { (Bleeker, ?) }\end{array}$ & $\mathrm{S}$ & $\begin{array}{l}\text { Taken from the holothurian Actinopyga } \\
\text { obesa in the lagoon. Indo-West Pacific. } \\
\text { RUSI No:044311 }\end{array}$ & 5 specimens & NE \\
\hline $\begin{array}{l}\text { Carapus mourlani } \\
\text { (Petit, 1934) }\end{array}$ & $\mathrm{S}$ & $\begin{array}{l}\text { Taken from the holothurian Holothuria } \\
\text { atra in the lagoon. Indo-West Pacific. } \\
\text { RUSI No:044309 }\end{array}$ & 1 specimen & $\mathrm{NE}$ \\
\hline ATHERINIDAE & & SILVERSIDES & & \\
\hline $\begin{array}{l}\text { Hypoatherina temminckii } \\
\text { (Bleeker, 1853) }\end{array}$ & $\mathrm{S}$ & $\begin{array}{l}\text { Shoals occurred throughout the surface } \\
\text { waters of the lagoon and were often seen } \\
\text { preyed on by carangid fish. Indo-Pacific. }\end{array}$ & $\begin{array}{l}90 \text { specimens } \\
(50-100 \mathrm{TL})\end{array}$ & $\mathrm{NE}$ \\
\hline BELONIDAE & & NEEDLEFISHES & & \\
\hline $\begin{array}{l}\text { Strongylura leiura } \\
\text { (Bleeker, 1851) }\end{array}$ & $\mathrm{P}$ & Common in the lagoon. Indo-Pacific. & & $\mathrm{NE}$ \\
\hline HOLOCENTRIDAE & & SQUIRELFISHES & & \\
\hline $\begin{array}{l}\text { Neoniphon argenteus } \\
\text { (Valenciennes, 1831) }\end{array}$ & V\&S & $\begin{array}{l}\text { Lagoon, frequently seen around bommies. } \\
\text { Indo-West Pacific. }\end{array}$ & $60 \mathrm{FL}$ & $\mathrm{LC}$ \\
\hline
\end{tabular}




\begin{tabular}{|c|c|c|c|c|}
\hline Family and Species & Method & Habitat Notes & $\begin{array}{l}\text { Specimen Size } \\
(\mathbf{m m})\end{array}$ & $\begin{array}{c}\text { IUCN } \\
\text { Red } \\
\text { List } \\
\end{array}$ \\
\hline $\begin{array}{l}\text { Sargocentron } \\
\text { caudimaculatum } \\
\text { (Ruppell, 1838) }\end{array}$ & $\mathrm{V}$ & Lagoon and drop-off. Indo-Pacific. & & $\mathrm{LC}$ \\
\hline $\begin{array}{l}\text { Sargocentron diadema } \\
\text { (Lacepede, 1801) }\end{array}$ & $\mathrm{P} \& \mathrm{~S}$ & Reeftop and lagoon & $85 ; 105 \mathrm{FL}$ & $\mathrm{LC}$ \\
\hline $\begin{array}{l}\text { Sargocentron } \\
\text { punctatissimum } \\
\text { (Cuvier, 1829) }\end{array}$ & $\mathrm{P} \& \mathrm{~S}$ & Reeftop. Indo-Pacific. & $80 \mathrm{FL}$ & $\mathrm{LC}$ \\
\hline $\begin{array}{l}\text { Sargocentron spiniferum } \\
\text { (Forsskal, 1775) }\end{array}$ & $\mathrm{V}$ & $\begin{array}{l}\text { Seen under overhangs on the drop-off. } \\
\text { Indo-Pacific. }\end{array}$ & & $\mathrm{LC}$ \\
\hline $\begin{array}{l}\text { Myripristis adusta } \\
\text { Bleeker, } 1853\end{array}$ & $\mathrm{~V} \& \mathrm{P}$ & Lagoon. Indo-Pacific. & & $\mathrm{LC}$ \\
\hline $\begin{array}{l}\text { Myripristis berndti } \\
\text { Jordan \& Evermann, } \\
1903\end{array}$ & V\&S & $\begin{array}{l}\text { Common in the lagoon. Less so on the } \\
\text { drop-off. Indo-Pacific. RUSI No:043310 }\end{array}$ & 1 specimen & $\mathrm{LC}$ \\
\hline $\begin{array}{l}\text { Myripristis hexagona } \\
\text { (Lacepede, 1802) }\end{array}$ & $\mathrm{V}$ & Recorded from the drop-off. Indo-Pacific. & & $\mathrm{LC}$ \\
\hline $\begin{array}{l}\text { Myripristis kuntee } \\
\text { Cuvier, } 1831\end{array}$ & $\mathrm{~V}$ & Recorded from the drop-off. Indo-Pacific. & & $\mathrm{LC}$ \\
\hline $\begin{array}{l}\text { Myripristis melanosticta } \\
=\text { blotche Cuvier, } 1829\end{array}$ & $\mathrm{~V}$ & Lagoon and drop-off. Indo-West Pacific & & $\mathrm{LC}$ \\
\hline $\begin{array}{l}\text { Myripristis murdjan } \\
\text { (Forsskal, 1775) }\end{array}$ & $\mathrm{V}$ & $\begin{array}{l}\text { Recorded from the drop-off. Indo-West } \\
\text { Pacific. }\end{array}$ & & $\mathrm{LC}$ \\
\hline $\begin{array}{l}\text { Myripristis violacea } \\
\text { Bleeker, } 1851\end{array}$ & $\mathrm{~V}$ & $\begin{array}{l}\text { Recorded from the drop-off. Indo-West } \\
\text { Pacific. }\end{array}$ & & $\mathrm{LC}$ \\
\hline $\begin{array}{l}\text { Myripristis vittata } \\
\text { Cuvier, } 1831\end{array}$ & $\mathrm{P} \& \mathrm{~V}$ & $\begin{array}{l}\text { Recorded from the drop-off. Indo-West } \\
\text { Pacific. }\end{array}$ & & $\mathrm{LC}$ \\
\hline $\begin{array}{l}\text { Plectrypops lima } \\
\text { (Valenciennes, 1831) }\end{array}$ & $\mathrm{P} \& \mathrm{~S}$ & Lagoon. Indo-West Pacific & $50 \mathrm{FL}$ & $\mathrm{LC}$ \\
\hline SYNGNATHIDAE & & PIPEFISHES & & \\
\hline $\begin{array}{l}\text { Microphis brachyurus } \\
\text { (Bleeker, 1853) }\end{array}$ & $\mathrm{S}$ & Reeftop. Western Indian Ocean. & $110 \mathrm{TL}$ & $\mathrm{LC}$ \\
\hline SCORPAENIDAE & & SCORPIONFISHES & & \\
\hline $\begin{array}{l}\text { Pterois miles } \\
\text { (Bennet, 1828) }\end{array}$ & $\mathrm{P}$ & $\begin{array}{l}\text { Recorded from reeftop and lagoon. Indian } \\
\text { Ocean. }\end{array}$ & Adult & $\mathrm{LC}$ \\
\hline $\begin{array}{l}\text { Pterois radiate } \\
\text { Cuvier, } 1829\end{array}$ & $\mathrm{P}$ & Recorded from the lagoon. Indo-Pacific. & Adult & $\mathrm{LC}$ \\
\hline $\begin{array}{l}\text { Sebastapistes } \\
\text { cyanostigma (Bleeker, } \\
1856)\end{array}$ & $\mathrm{P}$ & Reeftop. Indo-Pacific. & $40 \mathrm{TL}$ & $\mathrm{LC}$ \\
\hline $\begin{array}{l}\text { Sebastapistes mauritiana } \\
\text { (Cuvier, 1829) }\end{array}$ & $\mathrm{S}$ & RUSI No:043307; Reeftop. Indo-Pacific. & 5 specimens & $\mathrm{LC}$ \\
\hline $\begin{array}{l}\text { Taenianotus triacanthus } \\
\text { Lacepede } 1802\end{array}$ & $\mathrm{~S}$ & Reeftop. Indo-Pacific. & $75 \mathrm{TL}$ & $\mathrm{LC}$ \\
\hline $\begin{array}{l}\text { Synanceia verrucosa } \\
\text { Bloch \& Schneider, } 1801\end{array}$ & $\mathrm{~S}$ & Reeftop. Indo-Pacific & $65 \mathrm{TL}$ & $\mathrm{LC}$ \\
\hline
\end{tabular}




\begin{tabular}{|c|c|c|c|c|}
\hline CARACANTHIDA & & CORAL CROUCHERS & & \\
\hline $\begin{array}{l}\text { Caracanthus } \\
\text { madagascariensis } \\
\text { (Guichenot, 1869) }\end{array}$ & $\mathrm{S}$ & Lagoon. Indian Ocean. & $38 ; 40 ; 45 \mathrm{TL}$ & $\mathrm{LC}$ \\
\hline $\begin{array}{l}\text { Caracanthus unipinna } \\
\text { (Gray, 1831) }\end{array}$ & $\mathrm{S}$ & Lagoon. Indo-Pacific. & $40 \mathrm{TL}$ & $\mathrm{LC}$ \\
\hline KUHLIIDAE & & FLAGTAILS & & \\
\hline $\begin{array}{l}\text { Kuhlia mugil (Schneider, } \\
\text { 1801) }\end{array}$ & $\mathrm{V}$ & $\begin{array}{l}\text { Common in pools at low tide on the } \\
\text { reeftop. Indo-Pacific. }\end{array}$ & & $\mathrm{LC}$ \\
\hline SERRANIDAE & & GROUPERS & & \\
\hline $\begin{array}{l}\text { Anthias evansi Smith, } \\
1954\end{array}$ & $\mathrm{~V}$ & $\begin{array}{l}\text { Common on the drop-off at depths of } 20- \\
30 \text { metres. Indian Ocean. }\end{array}$ & & $\mathrm{LC}$ \\
\hline $\begin{array}{l}\text { Pseudanthias } \\
\text { squamipinnis (Peters, } \\
\text { 1855) }\end{array}$ & $\mathrm{V}$ & $\begin{array}{l}\text { Common along the drop-offs and around } \\
\text { bommies in the deeper areas of the lagoon. } \\
\text { Indo-West Pacific. }\end{array}$ & & $\mathrm{LC}$ \\
\hline $\begin{array}{l}\text { Nemanthias carberryi } \\
\text { Smith, } 1954\end{array}$ & $\mathrm{~V}$ & $\begin{array}{l}\text { Common on the drop-offs to a depth of } 25 \\
\text { metres. Western Indian Ocean. }\end{array}$ & & $\mathrm{LC}$ \\
\hline $\begin{array}{l}\text { Aethaloperca rogaa } \\
\text { (Forsskal, 1775) }\end{array}$ & $\mathrm{V}$ & $\begin{array}{l}\text { Not common. Recorded from the lagoon } \\
\text { and on the drop-off. Indo-West Pacific. }\end{array}$ & & $\mathrm{LC}$ \\
\hline $\begin{array}{l}\text { Cephalopholis argus } \\
\text { Schneider, } 1801\end{array}$ & $\mathrm{~S} \& \mathrm{P}$ & $\begin{array}{l}\text { Reeftop. Most common serranid here and } \\
\text { in the lagoon. Indo-Pacific. }\end{array}$ & $170 ; 190 \mathrm{TL}$ & $\mathrm{LC}$ \\
\hline $\begin{array}{l}\text { Cephalopholis miniata } \\
\text { (Forsskal, 1775) }\end{array}$ & $\mathrm{P}$ & Lagoon and drop-off. Indo-West Pacific. & & $\mathrm{LC}$ \\
\hline $\begin{array}{l}\text { Cephalopholis urodeta } \\
\text { (Forster, 1801) 1828) }\end{array}$ & $\mathrm{V}$ & $\begin{array}{l}\text { Recorded from the lagoon and the drop-off. } \\
\text { Indian Ocean. }\end{array}$ & & $\mathrm{LC}$ \\
\hline $\begin{array}{l}\text { Epinephelus chlorostigma } \\
\text { (Valenciennes, 1828) }\end{array}$ & $\mathrm{V}$ & $\begin{array}{l}\text { Common in the lagoon and the drop-offs. } \\
\text { Indo-west Pacific. }\end{array}$ & & $\mathrm{LC}$ \\
\hline $\begin{array}{l}\text { Epinephelus macrospilos } \\
\text { (Bleeker, 1855) }\end{array}$ & $\mathrm{S} \& \mathrm{P}$ & $\begin{array}{l}\text { Common amongst coral heads on reeftop. } \\
\text { Indo-West Pacific. }\end{array}$ & $200 \mathrm{TL}$ & $\mathrm{LC}$ \\
\hline $\begin{array}{l}\text { Epinephelus } \\
\text { fuscoguttatus (Forsskal, } \\
1775 \text { ) }\end{array}$ & $\mathrm{V}$ & $\begin{array}{l}\text { Large specimens (up to } 700 \mathrm{~mm} \text { ) common, } \\
\text { juveniles very common amongst coral } \\
\text { bommies in the lagoon. Indo-West Pacific. }\end{array}$ & & $\mathbf{V U}$ \\
\hline $\begin{array}{l}\text { Epinephelus lanceolatus } \\
\text { (Bloch, 1790) }\end{array}$ & $\mathrm{V}$ & $\begin{array}{l}\text { Several large specimens seen on the drop- } \\
\text { off. Indo-Pacific. }\end{array}$ & & DD \\
\hline $\begin{array}{l}\text { Epinephelus merra } \\
\text { Bloch, } 1793\end{array}$ & $\mathrm{P} \& \mathrm{~S}$ & $\begin{array}{l}\text { Common in pools on the reeftop. Indo- } \\
\text { West Pacific. }\end{array}$ & $205 ; 210 \mathrm{TL}$ & $\mathrm{LC}$ \\
\hline $\begin{array}{l}\text { Epinephelus } \\
\text { polyphekadion (Bleeker, } \\
1873 \text { ) }\end{array}$ & $\mathrm{P}$ & $\begin{array}{l}\text { Common amongst bommies in the lagoon. } \\
\text { Indo-Pacific. }\end{array}$ & & $\mathrm{LC}$ \\
\hline $\begin{array}{l}\text { Epinephelus multinotatus } \\
\text { (Peters, 1876) }\end{array}$ & $\mathrm{P}$ & Recorded from the drop-off. Indian Ocean. & & $\mathrm{LC}$ \\
\hline $\begin{array}{l}\text { Epinephelus spilotoceps } \\
\text { (Schultz, 1953) }\end{array}$ & $\mathrm{V} \& \mathrm{~S}$ & Reeftop. Indo-West Pacific. & $250 ; 260 \mathrm{TL}$ & $\mathrm{LC}$ \\
\hline $\begin{array}{l}\text { Epinephelus tukula } \\
\text { Morgans, } 1959\end{array}$ & $\mathrm{~V} \& \mathrm{C}$ & $\begin{array}{l}\text { Numerous large specimens seen on drop- } \\
\text { off. Indo-West Pacific. }\end{array}$ & $\begin{array}{l}\text { Commercial } \\
\text { record }\end{array}$ & $\mathrm{LC}$ \\
\hline $\begin{array}{l}\text { Gracila albomarginata } \\
\text { (Fowler \& Bean, 1930) }\end{array}$ & $\mathrm{V}$ & $\begin{array}{l}\text { A single specimen seen; drop-off at } 22 \\
\text { metres. Indo-Pacific. }\end{array}$ & & $\mathrm{LC}$ \\
\hline $\begin{array}{l}\text { Plectropomus areolatus } \\
\text { Ruppell, } 1828\end{array}$ & $\mathrm{~V} \& \mathrm{C}$ & $\begin{array}{l}\text { Several large specimens seen both in the } \\
\text { lagoon and on the drop-off. Indo-Pacific. }\end{array}$ & $\begin{array}{l}\text { Commercial } \\
\text { record }\end{array}$ & $\mathbf{V U}$ \\
\hline
\end{tabular}




\begin{tabular}{|c|c|c|c|c|}
\hline Family and Species & Method & Habitat Notes & $\begin{array}{l}\text { Specimen Size } \\
(\mathbf{m m})\end{array}$ & $\begin{array}{l}\text { IUCN } \\
\text { Red } \\
\text { List } \\
\end{array}$ \\
\hline $\begin{array}{l}\text { Plectropomus laevis } \\
\text { (Lacepede, 1801) }\end{array}$ & $\mathrm{P} \& \mathrm{C}$ & $\begin{array}{l}\text { Large adult fish recorded from the lagoon } \\
\text { and drop-off. Indo-Pacific. }\end{array}$ & $\begin{array}{l}\text { Commercial } \\
\text { record }\end{array}$ & VU \\
\hline $\begin{array}{l}\text { Plectropomus punctatus } \\
\text { Quoy \& Gaimard, } 1824\end{array}$ & $\mathrm{P} \& \mathrm{C}$ & $\begin{array}{l}\text { Common at the drop-off on the sheltered } \\
\text { north west side of the atoll. Recorded from } \\
\text { the lagoon but less common there. Western } \\
\text { Indian Ocean. }\end{array}$ & $\begin{array}{l}\text { Commercial } \\
\text { record }\end{array}$ & $\mathrm{LC}$ \\
\hline $\begin{array}{l}\text { Variola louti (Forsskal, } \\
1775 \text { ) }\end{array}$ & $\mathrm{V} \& \mathrm{C}$ & $\begin{array}{l}\text { Recorded at the drop-off. Indo-West } \\
\text { Pacific. }\end{array}$ & $\begin{array}{l}\text { Commercial } \\
\text { record }\end{array}$ & $\mathrm{LC}$ \\
\hline $\begin{array}{l}\text { Grammisties sexlineatus } \\
\text { (Thunberg, 1792) }\end{array}$ & $\mathrm{V}$ & $\begin{array}{l}\text { Found singly throughout the lagoon and } \\
\text { reef. Widespread in the Indo-Pacific. }\end{array}$ & & $\mathrm{LC}$ \\
\hline PSEUDOCHROMIDAE & & DOTTYBACKS & & \\
\hline $\begin{array}{l}\text { Pseudochromis fridmani } \\
\text { (Klausewitz 1968) }\end{array}$ & $\mathrm{V}$ & Common throughout lagoon. & & $\mathrm{NE}$ \\
\hline $\begin{array}{l}\text { Pseudochromis dutoiti } \\
\text { Smith, } 1955\end{array}$ & $\mathrm{~V}$ & Common throughout lagoon. & & $\mathrm{NE}$ \\
\hline PRIACANTHIDAE & & BIGEYES & & \\
\hline $\begin{array}{l}\text { Priacanthus cruentatus } \\
\text { (Lacepede, 1801) }\end{array}$ & $\mathrm{V}$ & $\begin{array}{l}\text { Recorded from the drop-off. } \\
\text { Circumtropical. }\end{array}$ & & $\mathrm{LC}$ \\
\hline $\begin{array}{l}\text { Priacanthus hamrur } \\
\text { (Forskal, 1775) }\end{array}$ & $\mathrm{V}$ & $\begin{array}{l}\text { Recorded from the lagoon and the drop-off. } \\
\text { Indo-Pacific. }\end{array}$ & & $\mathrm{LC}$ \\
\hline APOGONIDAE & & CARDINAL FISHES & & \\
\hline $\begin{array}{l}\text { Apogon angustatus } \\
\text { (Smith \& Radcliffe, } \\
\text { 1911) }\end{array}$ & $\mathrm{P} \& \mathrm{~S}$ & Collected from the lagoon. Indo-Pacific. & $\begin{array}{l}\text { Identified by J. } \\
\text { Randall. }\end{array}$ & $\mathrm{NE}$ \\
\hline $\begin{array}{l}\text { Apogon apogonides } \\
\text { (Bleeker, 1856) }\end{array}$ & $\mathrm{P}$ & Recorded from the lagoon. & & $\mathrm{NE}$ \\
\hline $\begin{array}{l}\text { Apogon aureus } \\
\text { (Lacepede, } 1802 \text { ) }\end{array}$ & $\mathrm{V}$ & $\begin{array}{l}\text { Recorded from the lagoon. Indo-West } \\
\text { Pacific. }\end{array}$ & & $\mathrm{NE}$ \\
\hline $\begin{array}{l}\text { Apogon cookii Macleay, } \\
1881\end{array}$ & $\mathrm{P} \& \mathrm{~S}$ & Collected from the lagoon. Indo-Pacific. & $62 \mathrm{FL}$ & $\mathrm{NE}$ \\
\hline $\begin{array}{l}\text { Apogon kallopterus } \\
\text { Bleeker, } 1856\end{array}$ & $\mathrm{P} \& \mathrm{~S}$ & Collected from the lagoon. Indo-Pacific. & $65 ; 85 ; 90 ; 95 \mathrm{FL}$ & $\mathrm{NE}$ \\
\hline $\begin{array}{l}\text { Apogon semiornatus } \\
\text { Peters, } 1876\end{array}$ & $\mathrm{P} \& \mathrm{~S}$ & Reeftop. Indo-West Pacific. & $40 ; 42 ; 45 \mathrm{TL}$ & $\mathrm{NE}$ \\
\hline $\begin{array}{l}\text { Cheilodipterus macrodon } \\
\text { (Lacepede, 1802) }\end{array}$ & $\mathrm{V}$ & $\begin{array}{l}\text { Recorded from the lagoon. Western Indian } \\
\text { Ocean. }\end{array}$ & & $\mathrm{NE}$ \\
\hline $\begin{array}{l}\text { Cheilodipterus } \\
\text { quinquelineatus Cuvier, } \\
1828\end{array}$ & $\mathrm{~S}$ & Common on the reeftop. Indo-Pacific. & $\begin{array}{l}\text { 65;65;95;95;95; } \\
\text { 95;105 FL }\end{array}$ & $\mathrm{NE}$ \\
\hline $\begin{array}{l}\text { Foa brachygramma } \\
\text { (Jenkins, 1903) }\end{array}$ & $\mathrm{V}$ & Recorded from the lagoon. Indo-Pacific. & & $\mathrm{NE}$ \\
\hline $\begin{array}{l}\text { Fowleria aurita } \\
\text { (Valenciennes, 1831) }\end{array}$ & $\mathrm{V}$ & $\begin{array}{l}\text { Seen under ledges in pools on the reeftop. } \\
\text { Indo-Pacific. }\end{array}$ & & $\mathrm{NE}$ \\
\hline $\begin{array}{l}\text { Siphamia mossambica } \\
\text { Smith, } 1955\end{array}$ & $\mathrm{~S}$ & Reeftop. Western Indian Ocean & $\begin{array}{l}\text { 26;90 FL Plus } \\
\text { one }\end{array}$ & $\mathrm{NE}$ \\
\hline
\end{tabular}




\begin{tabular}{|c|c|c|c|c|}
\hline HAEMULIDAE & & RUBBERLIPS & & \\
\hline $\begin{array}{l}\text { Diagramma centurio } \\
\text { (Cuvier, } 1830 \text { ) }\end{array}$ & $\mathrm{V} \& \mathrm{C}$ & In the lagoon, Indo-West Pacific. & not preserved & $\mathrm{NE}$ \\
\hline $\begin{array}{l}\text { Plectorhinchus orientalis } \\
\text { (Bloch,1793) }\end{array}$ & $\mathrm{P}$ & $\begin{array}{l}\text { At the entrance channel to the lagoon. Indo- } \\
\text { Pacific. }\end{array}$ & & $\mathrm{LC}$ \\
\hline LUTJANIDAE & & SNAPPERS & & \\
\hline $\begin{array}{l}\text { Aphareus furca } \\
\text { (Lacepede, 1801) }\end{array}$ & $\mathrm{S}$ & Deep towards the drop-off. Indo-Pacific. & $\begin{array}{l}\text { Line-caught: } \\
380 \mathrm{FL}\end{array}$ & $\mathrm{LC}$ \\
\hline $\begin{array}{l}\text { Aprion virescens } \\
\text { (Valenciennes, 1830) }\end{array}$ & $\mathrm{V} \& \mathrm{~S}$ & $\begin{array}{l}\text { A few large specimens seen in the lagoon } \\
\text { and one caught on a trolled lure. Indo- } \\
\text { Pacific. }\end{array}$ & $650 \mathrm{FL}$ & $\mathrm{LC}$ \\
\hline $\begin{array}{l}\text { Lutjanus bohar (Forsskal, } \\
\text { 1775) }\end{array}$ & $\mathrm{P} \& \mathrm{~S}$ & $\begin{array}{l}\text { A ubiquitous fish of the lagoon, }(600-700 \\
\text { mm TL). Commercial line fishers reported } \\
\text { large catches of } L . \text { bohar at depth of } 30 \\
\text { metres. Indo-West Pacific. }\end{array}$ & $\begin{array}{l}200 \mathrm{FL} \\
\text { Commercial } \\
\text { record }\end{array}$ & $\mathrm{LC}$ \\
\hline $\begin{array}{l}\text { Lutjanus fulvus } \\
\text { (Schneider, 1801) }\end{array}$ & $\mathrm{P}$ & $\begin{array}{l}\text { A single individual from the lagoon. Indo- } \\
\text { West Pacific. }\end{array}$ & & $\mathrm{LC}$ \\
\hline $\begin{array}{l}\text { Lutjanus gibbus } \\
\text { (Forsskal, 1775) }\end{array}$ & $\mathrm{V} \& \mathrm{P}$ & $\begin{array}{l}\text { Large shoals common around the bigger } \\
\text { coral bommies in the lagoon and in pools } \\
\text { on reeftop. Indo-West Pacific. }\end{array}$ & & $\mathrm{LC}$ \\
\hline $\begin{array}{l}\text { Lutjanus kasmira } \\
\text { (Forsskal, 1775) }\end{array}$ & $\mathrm{V} \& \mathrm{P}$ & $\begin{array}{l}\text { Common in shoals both in the lagoon and } \\
\text { along the drop-offs. Indo-West Pacific. }\end{array}$ & & $\mathrm{LC}$ \\
\hline $\begin{array}{l}\text { Lutjanus rivulatus } \\
\text { (Cuvier, 1828) }\end{array}$ & $\mathrm{V}$ & $\begin{array}{l}\text { A single adult seen on the drop-off. Indo } \\
\text { West Pacific. }\end{array}$ & & $\mathrm{LC}$ \\
\hline $\begin{array}{l}\text { Macolor niger (Forsskal, } \\
1775 \text { ) }\end{array}$ & $\mathrm{V}$ & $\begin{array}{l}\text { Individuals seen in the lagoon and on the } \\
\text { drop-off. Indo-Pacific. }\end{array}$ & & $\mathrm{LC}$ \\
\hline $\begin{array}{l}\text { Pristipomoides } \\
\text { filamentosus } \\
\text { (Valenciennes, 1830) }\end{array}$ & $\mathrm{C}$ & $\begin{array}{l}\text { Numerous specimens caught on line from a } \\
\text { depth of } 50 \mathrm{~m} .\end{array}$ & & $\mathrm{LC}$ \\
\hline CAESIONIDAE & & FUSILIERS & & \\
\hline $\begin{array}{l}\text { Pterocaesio tile (Cuvier } \\
\text { \& Valenciennes, 1830) }\end{array}$ & $\mathrm{VS}$ & Common in lagoon. Western Indian Ocean. & $\begin{array}{l}145 ; 155 ; 155 \\
\text { FL }\end{array}$ & $\mathrm{LC}$ \\
\hline $\begin{array}{l}\text { Pterocaesio capricornis } \\
\text { Smith \& Smith, } 1963\end{array}$ & $\mathrm{P}$ & $\begin{array}{l}\text { Single specimen recorded from the lagoon. } \\
\text { Western Indian Ocean islands. Identified } \\
\text { from photo by K. Carpenter. }\end{array}$ & & $\mathrm{DD}$ \\
\hline $\begin{array}{l}\text { Caesio xanthonota } \\
\text { Bleeker, } 1853\end{array}$ & $\mathrm{~V}$ & $\begin{array}{l}\text { Shoals common in lagoon and on drop -off. } \\
\text { Indo-West Pacific. }\end{array}$ & & $\mathrm{LC}$ \\
\hline $\begin{array}{l}\text { Caesio caerulaurea } \\
\text { Lacepede, } 1801\end{array}$ & V\&S & $\begin{array}{l}\text { Large shoals common in the lagoon and on } \\
\text { drop-off. Indo-Pacific. }\end{array}$ & $170 \mathrm{FL}$ & $\mathrm{LC}$ \\
\hline Caesio teres Seale, 1906 & $\mathrm{~V}$ & $\begin{array}{l}\text { Common in the lagoon. Western Indian } \\
\text { Ocean. }\end{array}$ & & $\mathrm{LC}$ \\
\hline LETHRINIDAE & & SAVENGERS & & \\
\hline $\begin{array}{l}\text { Gnathodentex } \\
\text { aureolineatus (Lacepede, } \\
\text { 1802) }\end{array}$ & $\mathrm{P}$ & $\begin{array}{l}\text { Large shoals common in the lagoon near } \\
\text { bommies. Indo-West Pacific. }\end{array}$ & & $\mathrm{LC}$ \\
\hline $\begin{array}{l}\text { Lethrinus microdon } \\
\text { Valenciennes, } 1830\end{array}$ & $\mathrm{~V} \& \mathrm{C}$ & $\begin{array}{l}\text { Caught at the drop-off on a line. Indo-West } \\
\text { Pacific. }\end{array}$ & & $\mathrm{LC}$ \\
\hline $\begin{array}{l}\text { Lethrinus harak } \\
\text { (Forsskal, 1775) }\end{array}$ & $\mathrm{V}$ & $\begin{array}{l}\text { Common over sand in the lagoon. Indo- } \\
\text { West Pacific. }\end{array}$ & & $\mathrm{LC}$ \\
\hline
\end{tabular}




\begin{tabular}{|c|c|c|c|c|}
\hline Family and Species & Method & Habitat Notes & $\begin{array}{l}\text { Specimen Size } \\
(\mathbf{m m})\end{array}$ & $\begin{array}{l}\text { IUCN } \\
\text { Red } \\
\text { List } \\
\end{array}$ \\
\hline $\begin{array}{l}\text { Lethrinus nebulosus } \\
\text { (Forsskal, 1775) }\end{array}$ & $\mathrm{V} / \mathrm{C}$ & $\begin{array}{l}\text { A single large adult speared from a shoal of } \\
\text { approximately twenty fish over sand in the } \\
\text { lagoon. Indo-West Pacific. }\end{array}$ & & $\mathrm{LC}$ \\
\hline $\begin{array}{l}\text { Lethrinus mahsena } \\
\text { (Forsskal, 1775) }\end{array}$ & $\mathrm{V}$ & $\begin{array}{l}\text { A single specimen seen over sand in the } \\
\text { lagoon. This fish was previously known as } \\
\text { L. sanguineus but is, according to "The } \\
\text { World Catalogue of Lethrinid Fishes" by } \\
\text { K. Carpenter a colour morph of } L \text {. } \\
\text { mahsena. Western Indian Ocean. }\end{array}$ & & $\mathrm{LC}$ \\
\hline $\begin{array}{l}\text { Lethrinus variegatus } \\
\text { (Ehrenberg, 1830) }\end{array}$ & $\mathrm{V}$ & $\begin{array}{l}\text { Seen over sand in the lagoon. Indo-West } \\
\text { Pacific. }\end{array}$ & & $\mathrm{LC}$ \\
\hline $\begin{array}{l}\text { Lethrinus xanthochilus } \\
\text { (Klunzinger, 1870) }\end{array}$ & $\mathrm{V}$ & $\begin{array}{l}\text { A single specimen seen in the lagoon. Indo- } \\
\text { Pacific. }\end{array}$ & & $\mathrm{LC}$ \\
\hline $\begin{array}{l}\text { Monotaxis grandoculis } \\
\text { (Forsskal, 1775) }\end{array}$ & $\mathrm{V} \& \mathrm{P}$ & $\begin{array}{l}\text { Juveniles common in lagoon; adults in } \\
\text { deeper drop off. Indo West Pacific. }\end{array}$ & & $\mathrm{LC}$ \\
\hline NEMIPTERIDAE & & SPINECHEEKS & & \\
\hline $\begin{array}{l}\text { Scolopsis ghanam } \\
\text { (Forsskal, 1775) }\end{array}$ & $\mathrm{V} \& \mathrm{P}$ & $\begin{array}{l}\text { A few solitary specimens seen in the } \\
\text { lagoon near bommies. Western Indian } \\
\text { Ocean. }\end{array}$ & & $\mathrm{LC}$ \\
\hline KYPHOSIDAE & & CHUBS & & \\
\hline $\begin{array}{l}\text { Kyphosus vaigiensis } \\
\text { (Quoy \& Gaimard, 1825) }\end{array}$ & $\mathrm{V}$ & $\begin{array}{l}\text { Large numbers were seen on the reef-top at } \\
\text { high tide near the wreck of the Pep Ice- } \\
\text { Indo-Pacific. }\end{array}$ & & $\mathrm{LC}$ \\
\hline MULLIDAE & & GOATFISHES & & \\
\hline $\begin{array}{l}\text { Mulloides flavolineatus } \\
\text { (Lacepede, 1801) }\end{array}$ & $\mathrm{V}$ & Common in the lagoon. Indo-West Pacific. & & $\mathrm{LC}$ \\
\hline $\begin{array}{l}\text { Mulloides vanicolensis } \\
\text { (Valenciennes, 1831) }\end{array}$ & $\mathrm{V}$ & Common in the lagoon. Indo-West Pacific. & & $\mathrm{LC}$ \\
\hline $\begin{array}{l}\text { Parupeneus barberinus } \\
\text { (Lacepede, 1801) }\end{array}$ & $\mathrm{V}$ & $\begin{array}{l}\text { Common in pools on the reeftop and in the } \\
\text { lagoon. Indo-West Pacific. }\end{array}$ & & $\mathrm{LC}$ \\
\hline $\begin{array}{l}\text { Parupeneus bifasciatus } \\
\text { (Lacepede, 1801) }\end{array}$ & $\mathrm{V}$ & $\begin{array}{l}\text { Seen in the lagoon and on the drop-off. } \\
\text { Indo-West Pacific. }\end{array}$ & & $\mathrm{LC}$ \\
\hline $\begin{array}{l}\text { Parupeneus cyclostomus } \\
\text { (Lacepede, 1801) }\end{array}$ & $\mathrm{V}$ & $\begin{array}{l}\text { Recorded from the lagoon. Indo-West } \\
\text { Pacific. }\end{array}$ & & $\mathrm{LC}$ \\
\hline $\begin{array}{l}\text { Parupeneus indicus } \\
\text { (Shaw, 1803) }\end{array}$ & $\mathrm{V}$ & Common in the lagoon. Indo-West Pacific. & & $\mathrm{LC}$ \\
\hline $\begin{array}{l}\text { Parupeneus macronema } \\
\text { (Lacepede, 1801) }\end{array}$ & $\mathrm{S} / \mathrm{V}$ & $\begin{array}{l}\text { Common in pools on the reeftop. Indian } \\
\text { Ocean. }\end{array}$ & $\begin{array}{l}130 ; 135 ; 165 \\
\text { FL }\end{array}$ & $\mathrm{LC}$ \\
\hline $\begin{array}{l}\text { Parupeneus pleurostigma } \\
\text { (Bennett, 1831) }\end{array}$ & $\mathrm{V}$ & $\begin{array}{l}\text { Recorded from the lagoon. Indo-West } \\
\text { Pacific. }\end{array}$ & & $\mathrm{LC}$ \\
\hline MALACANTHIDAE & & TILEFISHES & & \\
\hline $\begin{array}{l}\text { Malacanthus brevirostris } \\
\text { (Guichenot, 1848) }\end{array}$ & $\mathrm{V}$ & $\begin{array}{l}\text { Recorded from the lagoon near bommies. } \\
\text { Indo-Pacific. }\end{array}$ & & $\mathrm{LC}$ \\
\hline $\begin{array}{l}\text { Malacanthus latovittatus } \\
\text { (Lacepede, 1801) }\end{array}$ & $\mathrm{V}$ & $\begin{array}{l}\text { Several seen over sand in the lagoon. Indo- } \\
\text { West Pacific. }\end{array}$ & & $\mathrm{LC}$ \\
\hline
\end{tabular}




\begin{tabular}{|c|c|c|c|c|}
\hline POMACANTHIDAE & & ANGELFISHES & & \\
\hline $\begin{array}{l}\text { Apolemichthys } \\
\text { trimaculatus (Lacepede, } \\
\text { 1831) }\end{array}$ & $\mathrm{V}$ & $\begin{array}{l}\text { Frequently seen in the lagoon near } \\
\text { bommies and on the drop-off. Indo-West } \\
\text { Pacific. }\end{array}$ & & $\mathrm{LC}$ \\
\hline $\begin{array}{l}\text { Centropyge bispinosus } \\
\text { (Gunther, 1860) }\end{array}$ & $\mathrm{V}$ & $\begin{array}{l}\text { Recorded from pools on the reeftop. Indo- } \\
\text { West Pacific. }\end{array}$ & & $\mathrm{LC}$ \\
\hline $\begin{array}{l}\text { Centropyge multispinis } \\
\text { (Playfair, 1867) }\end{array}$ & $\mathrm{S} / \mathrm{V}$ & Reeftop. Indo-West Pacific. & $\begin{array}{c}55 ; 64 ; 80 ; 81 ; \\
93 ; 100 ; 110, \mathrm{FL}\end{array}$ & $\mathrm{LC}$ \\
\hline $\begin{array}{l}\text { Genicanthus } \\
\text { caudovittatus (Gunther, } \\
1860 \text { ) }\end{array}$ & $\mathrm{V}$ & $\begin{array}{l}\text { Single specimen seen on drop-off. Western } \\
\text { Indian Ocean. }\end{array}$ & & $\mathrm{LC}$ \\
\hline $\begin{array}{l}\text { Pomacanthus imperator } \\
\text { (Bloch, 1787) }\end{array}$ & $\mathrm{V}$ & $\begin{array}{l}\text { Seen in the lagoon and on the drop-off. } \\
\text { Juveniles seen in reeftop pools. Indo-West } \\
\text { Pacific. }\end{array}$ & & $\mathrm{LC}$ \\
\hline $\begin{array}{l}\text { Pomacanthus } \\
\text { semicirculatus (Cuvier, } \\
1831 \text { ) }\end{array}$ & $\mathrm{V} \& \mathrm{P}$ & $\begin{array}{l}\text { Adults recorded from lagoon and drop-off } \\
\text { juveniles seen in reeftop pools. Indo-West } \\
\text { Pacific. }\end{array}$ & & $\mathrm{LC}$ \\
\hline $\begin{array}{l}\text { Pygoplites diacanthus } \\
\text { (Boddaert, 1772) }\end{array}$ & $\mathrm{V}$ & $\begin{array}{l}\text { Recorded from the drop-off. Indo-West } \\
\text { Pacific. }\end{array}$ & & $\mathrm{LC}$ \\
\hline CHAETODONTIDAE & & BUTTERFLYFISHES & & \\
\hline $\begin{array}{l}\text { Chaetodon auriga } \\
\text { (Forsskal, 1775) }\end{array}$ & $\mathrm{P} \& \mathrm{~S}$ & $\begin{array}{l}\text { Probably the most common butterfly fish in } \\
\text { the lagoon and on the reeftop. Indo-Pacific. }\end{array}$ & $\begin{array}{l}140 ; 145+12 x \\
(110-145) \mathrm{TL} \\
\end{array}$ & $\mathrm{LC}$ \\
\hline $\begin{array}{l}\text { Chaetodon bennetti } \\
\text { (Cuvier, 1831) }\end{array}$ & $\mathrm{V} \& \mathrm{P}$ & Recorded from the lagoon. Indo-Pacific. & & $\mathrm{LC}$ \\
\hline $\begin{array}{l}\text { Chaetodon blackburnii } \\
\text { (Desjardins, 1836) }\end{array}$ & $\mathrm{V}$ & Common throughout & & $\mathrm{LC}$ \\
\hline $\begin{array}{l}\text { Chaetodon falcula } \\
\text { (Bloch, 1793) }\end{array}$ & $\mathrm{V} \& \mathrm{P}$ & Taxonomic query & & $\mathrm{LC}$ \\
\hline $\begin{array}{l}\text { Chaetodon guttatissimus } \\
\text { (Bennet, 1823) }\end{array}$ & $\mathrm{V} \& \mathrm{P}$ & $\begin{array}{l}\text { Common around bommies in the lagoon } \\
\text { and on reeftop. Indian Ocean. }\end{array}$ & & $\mathrm{LC}$ \\
\hline $\begin{array}{l}\text { Chaetofdon kleinii } \\
\text { (Bloch,1790) }\end{array}$ & V\&S & $\begin{array}{l}\text { Common throughout the lagoon. Indo- } \\
\text { Pacific }\end{array}$ & $85 ; 90 ; 95 \mathrm{TL}$ & $\mathrm{LC}$ \\
\hline $\begin{array}{l}\text { Chaetodon lineolatus } \\
\text { (Quoy \& Gaimard, 1831) }\end{array}$ & $\mathrm{V}$ & Recorded from the lagoon. Indo-Pacific. & & $\mathrm{LC}$ \\
\hline $\begin{array}{l}\text { Chaetodon lunula } \\
\text { (Lacepede, 1803) }\end{array}$ & $\mathrm{V} \& \mathrm{P}$ & $\begin{array}{l}\text { Common in pairs in lagoon and drop-off. } \\
\text { Indo-Pacific. }\end{array}$ & & $\mathrm{LC}$ \\
\hline $\begin{array}{l}\text { Chaetodon } \\
\text { madagaskariensis (Ahl, } \\
1923)\end{array}$ & V\&S & $\begin{array}{l}\text { Common throughout the atoll. Indian } \\
\text { Ocean. }\end{array}$ & $38 ; 40 ; 45 \mathrm{TL}$ & $\mathrm{LC}$ \\
\hline $\begin{array}{l}\text { Chaetodon melannotus } \\
\text { (Bloch \& Schneider, } \\
1801 \text { ) }\end{array}$ & $\mathrm{V}$ & Mainly at drop-off & & $\mathrm{LC}$ \\
\hline $\begin{array}{l}\text { Chaetodon meyeri (Bloch } \\
\& \text { Schneider, 1801) }\end{array}$ & V\&S & Lagoon. Indo-Pacific. & $120 \mathrm{TL}$ & $\mathrm{LC}$ \\
\hline $\begin{array}{l}\text { Chaetodon trifascialis } \\
\text { (Quoy \& Gaimard, 1825) }\end{array}$ & $\mathrm{V}$ & Recorded from the lagoon. Indo-Pacific. & & $\mathrm{LC}$ \\
\hline $\begin{array}{l}\text { Chaetodon trifasciatus } \\
\text { (Mungo Park, 1797) }\end{array}$ & V\&S & Lagoon. Indo-Pacific. & $\begin{array}{c}4 \\
(107 ; 110 ; 115 \\
120 \mathrm{TL} \\
\end{array}$ & $\mathrm{LC}$ \\
\hline
\end{tabular}




\begin{tabular}{|c|c|c|c|c|}
\hline Family and Species & Method & Habitat Notes & $\begin{array}{l}\text { Specimen Size } \\
(\mathbf{m m})\end{array}$ & $\begin{array}{l}\text { IUCN } \\
\text { Red } \\
\text { List } \\
\end{array}$ \\
\hline $\begin{array}{l}\text { Chaetodon unimaculatus } \\
\text { (Bloch, 1787) }\end{array}$ & $\mathrm{V}$ & $\begin{array}{l}\text { Common in the lagoon and on the drop-off. } \\
\text { Indian Ocean. }\end{array}$ & & $\mathrm{LC}$ \\
\hline $\begin{array}{l}\text { Chaetodon } \\
\text { xanthocephalus (Bennett, } \\
1832 \text { ) }\end{array}$ & V\&S & $\begin{array}{l}\text { Recorded from pools on the reeftop. } \\
\text { Western Indian Ocean. }\end{array}$ & $130 ; 155 \mathrm{TL}$ & $\mathrm{LC}$ \\
\hline $\begin{array}{l}\text { Forcipiger flavissimus } \\
\text { (Jordan \& McGregor, } \\
\text { 1898) }\end{array}$ & $\mathrm{V}$ & $\begin{array}{l}\text { Common in the lagoon and on the drop-off. } \\
\text { Indo-Pacific. }\end{array}$ & & $\mathrm{LC}$ \\
\hline $\begin{array}{l}\text { Heniochus diphreutes } \\
\text { (Jordan, 1903) }\end{array}$ & $\mathrm{V}$ & $\begin{array}{l}\text { Common along the drop-off. Indo-West } \\
\text { Pacific. }\end{array}$ & & $\mathrm{LC}$ \\
\hline $\begin{array}{l}\text { Heniochus monoceros } \\
\text { (Cuvier, 1831) }\end{array}$ & $\mathrm{V}$ & $\begin{array}{l}\text { Recorded from the lagoon. Indo-West } \\
\text { Pacific }\end{array}$ & & $\mathrm{LC}$ \\
\hline CARANGIDAE & & KINGFISHES/ JACKS & & \\
\hline $\begin{array}{l}\text { Carangoides armatus } \\
\text { (Ruppell, 1830) }\end{array}$ & V\&S & Lagoon & $195 \mathrm{FL}$ & $\mathrm{LC}$ \\
\hline $\begin{array}{l}\text { Carangoides } \\
\text { fulvoguttatus (Forsskal, } \\
1775 \text { ) }\end{array}$ & $\mathrm{V} \& \mathrm{~S}$ & Lagoon. Indo-West Pacific. & $700 \mathrm{FL}$ & $\mathrm{LC}$ \\
\hline $\begin{array}{l}\text { Caranx ignobilis } \\
\text { (Forsskal, 1775) }\end{array}$ & $\mathrm{V} \& \mathrm{C}$ & $\begin{array}{l}\text { Very common carangid throughout the } \\
\text { atoll. Fish } 20-30 \mathrm{~kg} \text { some at } 40-50 \mathrm{~kg} \text {; in } \\
\text { the lagoon and on the drop-off. Indo-west } \\
\text { Pacific. }\end{array}$ & & $\mathrm{LC}$ \\
\hline $\begin{array}{l}\text { Caranx lugubris (Poey, } \\
1860 \text { ) }\end{array}$ & $\mathrm{V}$ & $\begin{array}{l}\text { Shoals of 5-10 fish common in lagoon and } \\
\text { over drop-off. Circumtropical. }\end{array}$ & & $\mathrm{LC}$ \\
\hline $\begin{array}{l}\text { Caranx melampygus } \\
\text { (Cuvier, 1833) }\end{array}$ & $\mathrm{V}$ & $\begin{array}{l}\text { Most common in the lagoon around coral } \\
\text { heads. Indo-Pacific. }\end{array}$ & & $\mathrm{LC}$ \\
\hline $\begin{array}{l}\text { Elagatis bipinnulata } \\
\text { (Quoy \& Gaimard, 1825) }\end{array}$ & V & Common over drop-off. Circumtropical. & & $\mathrm{LC}$ \\
\hline $\begin{array}{l}\text { Gnathanodon speciosus } \\
\text { (Forsskal, 1775) }\end{array}$ & $\mathrm{V}$ & $\begin{array}{l}\text { A single large specimen recorded from the } \\
\text { lagoon. Indo-Pacific }\end{array}$ & & $\mathrm{LC}$ \\
\hline $\begin{array}{l}\text { Trachinotus blochii } \\
\text { (Lacepede, 1801) }\end{array}$ & $\mathrm{V}$ & $\begin{array}{l}\text { Recorded from the lagoon. Indo-West } \\
\text { Pacific }\end{array}$ & & $\mathrm{LC}$ \\
\hline CIRRHITIDAE & & HAWKFISHES & & \\
\hline $\begin{array}{l}\text { Cirrhitichthys } \\
\text { oxycephalus (Bleeker, } \\
1855 \text { ) }\end{array}$ & V\&S & $\begin{array}{l}\text { Common on bommies in the lagoon. Indo- } \\
\text { Pacific. }\end{array}$ & $\begin{array}{c}13 \times(45-63 \\
\text { TL) }\end{array}$ & $\mathrm{LC}$ \\
\hline $\begin{array}{l}\text { Paracirrhites arcatus } \\
\text { (Cuvier, 1829) }\end{array}$ & V\&S & $\begin{array}{l}\text { Common on bommies in the lagoon. Indo- } \\
\text { Pacific. }\end{array}$ & $80 \mathrm{TL}$ & $\mathrm{LC}$ \\
\hline $\begin{array}{l}\text { Paracirrhites forsteri } \\
\text { (Schneider, 1801) }\end{array}$ & & $\begin{array}{l}\text { Common in the lagoon and on the drop-off. } \\
\text { Indo-Pacific. }\end{array}$ & & $\mathrm{LC}$ \\
\hline PEMPHERIDAE & & SWEEPERS & & \\
\hline $\begin{array}{l}\text { Pempheris schwenkii } \\
\text { (Bleeker, 1855) }\end{array}$ & $\mathrm{V} \& \mathrm{P}$ & $\begin{array}{l}\text { Reeftop. Identified from a photograph by } \\
\text { Dr Randall, Mooi-Milwaukee Museum. } \\
\text { Indo-West Pacific. }\end{array}$ & $\begin{array}{c}7 \times(106-155 \\
\text { TL })\end{array}$ & $\mathrm{NE}$ \\
\hline POMACENTRIDAE & & DAMSELFISHES & & \\
\hline $\begin{array}{l}\text { Abudefduf notatus (Day, } \\
\text { 1869) }\end{array}$ & $\mathrm{V}$ & $\begin{array}{l}\text { Recorded from the reeftop. Indo-West } \\
\text { Pacific. }\end{array}$ & & $\mathrm{LC}$ \\
\hline
\end{tabular}




\begin{tabular}{|c|c|c|c|c|}
\hline $\begin{array}{l}\text { Abudefduf } \\
\text { septemfasciatus (Cuvier, } \\
1830)\end{array}$ & $\mathrm{V} \& \mathrm{P}$ & $\begin{array}{l}\text { Common throughout the lagoon. Indo-West } \\
\text { Pacific. }\end{array}$ & & \\
\hline $\begin{array}{l}\text { Abudefduf vaigiensis } \\
\text { (Quoy \& Gaimard, } 1825\end{array}$ & $\mathrm{~V} \& \mathrm{~S}$ & Lagoon. Indo-West Pacific. & $8 \times(40-95 \mathrm{FL})$ & $\mathrm{LC}$ \\
\hline $\begin{array}{l}\text { Amphiprion akallopisos } \\
\text { (Bleeker, 1853) }\end{array}$ & $\mathrm{V}$ & Recorded from the lagoon. Indian Ocean & & $\mathrm{LC}$ \\
\hline $\begin{array}{l}\text { Amphiprion allardi } \\
\text { (Klausewitz, 1970) }\end{array}$ & V\&S & Common in lagoon. Western Indian Ocean. & $52 ; 90 ; 120 \mathrm{TL}$ & $\mathrm{LC}$ \\
\hline $\begin{array}{l}\text { Chromis dimidiata } \\
\text { (Klunzinger, 1871) }\end{array}$ & $\mathrm{V} \& \mathrm{~S}$ & $\begin{array}{l}\text { Common throughout the lagoon and on the } \\
\text { drop-offs. Indian Ocean. }\end{array}$ & $\begin{array}{l}40 ; 45 ; 52 ; 55 ; 50 \\
50 ; 50 ; 50 \mathrm{TL}\end{array}$ & $\mathrm{LC}$ \\
\hline $\begin{array}{l}\text { Chromis lepidolepis } \\
\text { (Bleeker, 1877) }\end{array}$ & $\mathrm{V}$ & Common in the lagoon. Indo-Pacific. & & $\mathrm{LC}$ \\
\hline $\begin{array}{l}\text { Chromis nigrura (Smith, } \\
\text { 1960) }\end{array}$ & $\mathrm{V} \& \mathrm{~S}$ & $\begin{array}{l}\text { Found in large numbers over bommies in } \\
\text { the lagoon. West Indian Ocean }\end{array}$ & $7 \times(45-82 \mathrm{TL})$ & $\mathrm{NE}$ \\
\hline $\begin{array}{l}\text { Chromis opercularis } \\
\text { (Gunther, 1867) }\end{array}$ & $\mathrm{V}$ & Recorded from the lagoon. Indian Ocean. & & $\mathrm{NE}$ \\
\hline $\begin{array}{l}\text { Chromis ternatensis } \\
\text { (Bleeker, 1856) }\end{array}$ & $\mathrm{V}$ & Recorded from the lagoon. Indian Ocean. & & $\mathrm{NE}$ \\
\hline $\begin{array}{l}\text { Chrysiptera glauca } \\
\text { (Cuvier 1830) }\end{array}$ & $\mathrm{V} \& \mathrm{~S}$ & $\begin{array}{l}\text { Recorded from the lagoon. Indo-West } \\
\text { Pacific. RUSI: No: } 043305\end{array}$ & 2 specimens & $\mathrm{NE}$ \\
\hline $\begin{array}{l}\text { Chrysiptera unimaculata } \\
\text { (Cuvier, 1830) }\end{array}$ & & Reeftop. Indian Ocean. & $48 ; 54 ; 58 \mathrm{TL}$ & $\mathrm{NE}$ \\
\hline $\begin{array}{l}\text { Dascyllus aruanus } \\
\text { (Linnaeus, 1758) }\end{array}$ & V\&P\&S & $\begin{array}{l}\text { Only in lagoon, especially associated with } \\
\text { isolated bommies over sand. Juveniles. } \\
\text { abundant }\end{array}$ & $\begin{array}{l}30 ; 38 ; 45 ; 48 ; 50 \\
\text { FL }\end{array}$ & $\mathrm{NE}$ \\
\hline $\begin{array}{l}\text { Lepidozygus tapeinosoma } \\
\text { (Bleeker, 1856) }\end{array}$ & $\mathrm{V}$ & $\begin{array}{l}\text { Recorded from the drop-off. Indo-West } \\
\text { Pacific. }\end{array}$ & & $\mathrm{NE}$ \\
\hline $\begin{array}{l}\text { Plectroglyphidodon dickii } \\
\text { (Lienard, 1839) }\end{array}$ & $\mathrm{V}$ & $\begin{array}{l}\text { Throughout the lagoon and on the drop-off. } \\
\text { Indo-West Pacific. }\end{array}$ & & $\mathrm{NE}$ \\
\hline $\begin{array}{l}\text { Plectroglyphidodon } \\
\text { lacrymatus (Quoy \& } \\
\text { Gaimard, 1825) }\end{array}$ & $\mathrm{P}$ & Lagoon. Indo-West Pacific & $55 ; 72 \mathrm{FL}$ & \\
\hline $\begin{array}{l}\text { Plectroglyphidodon } \\
\text { leucozonus (Bleeker, } \\
\text { 1859) }\end{array}$ & V\&S & Common in lagoon and reef top & $48-57 \mathrm{FL}$ & $\mathrm{NE}$ \\
\hline $\begin{array}{l}\text { Pomacentrus caeruleus } \\
\text { (Quoy \& Gaimard, 1825) }\end{array}$ & $\mathrm{V} \& \mathrm{P}$ & $\begin{array}{l}\text { Recorded from the lagoon. A specimen } \\
\text { photographed in the lagoon by D. King } \\
\text { exhibited the same unusual colour phase } \\
\text { seen by J. Randall in specimens collected } \\
\text { from Oman. This phase shows the head, } \\
\text { anterior dorsal half of the body and the } \\
\text { dorsal fins as a light green colour. Our } \\
\text { specimen was identified from a } \\
\text { transparency by J. Randall. Western Indian } \\
\text { Ocean. }\end{array}$ & & $\mathrm{NE}$ \\
\hline $\begin{array}{l}\text { Pomacentrus pavo } \\
\text { (Bloch, 1787) }\end{array}$ & $\mathrm{P}$ & $\begin{array}{l}\text { Recorded from the lagoon. Indo-West } \\
\text { Pacific. }\end{array}$ & & $\mathrm{NE}$ \\
\hline
\end{tabular}




\begin{tabular}{|c|c|c|c|c|}
\hline Family and Species & Method & Habitat Notes & $\begin{array}{l}\text { Specimen Size } \\
(\mathbf{m m})\end{array}$ & $\begin{array}{l}\text { IUCN } \\
\text { Red } \\
\text { List } \\
\end{array}$ \\
\hline $\begin{array}{l}\text { Pomacentrus sulfureus } \\
\text { (Klunzinger, 1871) }\end{array}$ & $\mathrm{P} \& \mathrm{~S}$ & Recorded from the lagoon. Indo-Pacific. & $100 ; 118 \mathrm{FL}$ & $\mathrm{NE}$ \\
\hline $\begin{array}{l}\text { Stegastes nigricans } \\
\text { (Lacepede, 1803) }\end{array}$ & $\mathrm{P}$ & $\begin{array}{l}\text { Common on the sheltered north west side } \\
\text { of the atoll at the outer edge of the reeftop. } \\
\text { Indo-West Pacific. }\end{array}$ & $\begin{array}{l}\text { Identified from } \\
\text { photo by J. } \\
\text { Randall }\end{array}$ & $\mathrm{NE}$ \\
\hline $\begin{array}{l}\text { Stegastes lividus (Bloch } \\
\text { \& Schneider, 1801) }\end{array}$ & $\mathrm{P} \& \mathrm{~S}$ & $\begin{array}{l}\text { Found in association with the more } \\
\text { common } S \text {. nigricans. Indo-West Pacific. }\end{array}$ & $\begin{array}{l}100 ; 118 \mathrm{FL} \\
\text { Identified by P. } \\
\text { Heemstra. }\end{array}$ & $\mathrm{NE}$ \\
\hline LABRIDAE & & WRASSES & & \\
\hline $\begin{array}{l}\text { Labropsis xanthonota } \\
\text { (Randall, 1981) }\end{array}$ & $\mathrm{V} \& \mathrm{P}$ & $\begin{array}{l}\text { Not common. Recorded from around } \\
\text { bommies in the lagoon. Indo-Pacific. }\end{array}$ & & $\mathrm{LC}$ \\
\hline $\begin{array}{l}\text { Anampses twistii } \\
\text { (Bleeker, 1856) }\end{array}$ & $\mathrm{V} \& \mathrm{P}$ & $\begin{array}{l}\text { Recorded from around bommies in the } \\
\text { lagoon. Indo-Pacific. }\end{array}$ & & $\mathrm{LC}$ \\
\hline $\begin{array}{l}\text { Anampses } \\
\text { caeruleopunctatus } \\
\text { (Ruppell, 1829) }\end{array}$ & $\mathrm{V}$ & $\begin{array}{l}\text { Recorded from lagoon and drop-off. Indo- } \\
\text { Pacific. }\end{array}$ & & $\mathrm{LC}$ \\
\hline $\begin{array}{l}\text { Anampses lineatus } \\
\text { (Randall, 1972) }\end{array}$ & $\mathrm{V}$ & $\begin{array}{l}\text { Only recorded from the drop-off. Indian } \\
\text { Ocean. }\end{array}$ & & $\mathrm{LC}$ \\
\hline $\begin{array}{l}\text { Anampses meleagrides } \\
\text { (Valenciennes, 1840) }\end{array}$ & $\mathrm{V}$ & Lagoon \& reeftop. Indo-West Pacific & & \\
\hline $\begin{array}{l}\text { Bodianus anthioides } \\
\text { (Bennett, 1830) }\end{array}$ & V & Lagoon \& drop-off. Indo-Pacific. & & \\
\hline $\begin{array}{l}\text { Bodianus axillaris } \\
\text { (Bennett, 1831) }\end{array}$ & $\mathrm{V}$ & Lagoon \& drop-off. Indo-Pacific. & & \\
\hline $\begin{array}{l}\text { Bodianus bilunulatus } \\
\text { (Lacepede, 1801) }\end{array}$ & V & Drop-off. Indo-Pacific. & & $\mathrm{LC}$ \\
\hline $\begin{array}{l}\text { Bodianus diana } \\
\text { (Lacepede, 1801) }\end{array}$ & $\mathrm{V} \& \mathrm{P}$ & $\begin{array}{l}\text { A common wrasse throughout the atoll. } \\
\text { Indo-Pacific. }\end{array}$ & & $\mathrm{LC}$ \\
\hline $\begin{array}{l}\text { Cheilinus chlorourus } \\
\text { (Bloch, 1791) }\end{array}$ & $\mathrm{V}$ & Recorded from the lagoon. Indo-Pacific. & & $\mathrm{LC}$ \\
\hline $\begin{array}{l}\text { Cheilinus digrammus } \\
\text { (Lacepede, 1801) }\end{array}$ & V\&S & Recorded from the lagoon. Indo-Pacific. & $215 \mathrm{TL}$ & $\mathrm{LC}$ \\
\hline $\begin{array}{l}\text { Cheilinus trilobatus } \\
\text { (Lacepede, 1801) }\end{array}$ & $\mathrm{V}$ & Lagoon. Indo-West Pacific. & & $\mathrm{LC}$ \\
\hline $\begin{array}{l}\text { Cheilinus undulatus } \\
\text { (Ruppell, 1835) }\end{array}$ & $\mathrm{V} \& \mathrm{P}$ & $\begin{array}{l}\text { Numbers of large individuals recorded both } \\
\text { in the lagoon and on the north west drop- } \\
\text { off. Indo-Pacific }\end{array}$ & & EN \\
\hline $\begin{array}{l}\text { Cirrhilabrus exquisitus } \\
\text { (Smith, 1957) }\end{array}$ & $\mathrm{S} \& \mathrm{P}$ & Lagoon. Indo-Pacific. & $48 ; 55 ; 55 ; 62 \mathrm{TL}$ & DD \\
\hline $\begin{array}{l}\text { Coris aygula (Lacepede, } \\
1801)\end{array}$ & $\mathrm{V}$ & Recorded from the lagoon. Indo-Pacific. & & $\mathrm{LC}$ \\
\hline $\begin{array}{l}\text { Coris caudimacula (Quoy } \\
\text { \& Gaimard, 1834) }\end{array}$ & $\mathrm{V}$ & $\begin{array}{l}\text { Common in the lagoon and on the reeftop. } \\
\text { Indian Ocean. }\end{array}$ & & $\mathrm{LC}$ \\
\hline $\begin{array}{l}\text { Coris formosa (Bennett, } \\
1834)\end{array}$ & $\mathrm{V}$ & Recorded from the lagoon. Indian Ocean. & & $\mathrm{LC}$ \\
\hline $\begin{array}{l}\text { Coris gaimard africana } \\
\text { (Smith, 1957) }\end{array}$ & V & $\begin{array}{l}\text { Recorded from the lagoon. Western Indian } \\
\text { Ocean. }\end{array}$ & & $\mathrm{LC}$ \\
\hline
\end{tabular}




\begin{tabular}{|c|c|c|c|c|}
\hline $\begin{array}{l}\text { Cymolutes praetextatus } \\
\text { (Quoy \& Gaimard, 1834) }\end{array}$ & $\mathrm{P}$ & $\begin{array}{l}\text { Recorded from the lagoon. Identified from } \\
\text { a transparency by John E. Randall. Indo- } \\
\text { Pacific. }\end{array}$ & & LC \\
\hline $\begin{array}{l}\text { Epibulus insidiator } \\
\text { (Pallas, 1770) }\end{array}$ & $\mathrm{V}$ & $\begin{array}{l}\text { Individual specimens were recorded from } \\
\text { the lagoon (yellow colour phase) and on the } \\
\text { drop-off. Indo-Pacific. }\end{array}$ & & LC \\
\hline $\begin{array}{l}\text { Gomphosus caeruleus } \\
\text { (Lacepede, 1801) }\end{array}$ & $\mathrm{P} \& \mathrm{~S}$ & $\begin{array}{l}\text { Common in the lagoon and on the reeftop. } \\
\text { Indian Ocean. }\end{array}$ & $205 \mathrm{FL}$ & LC \\
\hline $\begin{array}{l}\text { Halichoeres hortulanus } \\
\text { (Lacepede, 1801) }\end{array}$ & V\&S & $\begin{array}{l}\text { Common in shallower parts of the atoll. } \\
\text { Indo-Pacific. }\end{array}$ & $217 \mathrm{TL}$ & LC \\
\hline $\begin{array}{l}\text { Halichoeres nebulosus } \\
\text { (Valenciennes, 1839) }\end{array}$ & $\mathrm{P} \& \mathrm{~S}$ & Lagoon. Indo-West Pacific. & $40 ; 85 \mathrm{TL}$ & LC \\
\hline $\begin{array}{l}\text { Halichoeres scapularis } \\
\text { (Bennett, 1831) }\end{array}$ & $\mathrm{P}$ & $\begin{array}{l}\text { Recorded from the lagoon over sand at the } \\
\text { edge of bommies. Identified from photo by } \\
\text { John E. Randall. Indo-West Pacific. }\end{array}$ & & LC \\
\hline $\begin{array}{l}\text { Hemigymnus fasciatus } \\
\text { (Bloch,1792) }\end{array}$ & $\mathrm{V}$ & Recorded from the lagoon. Indo-Pacific. & & LC \\
\hline $\begin{array}{l}\text { Hemigymnus melapterus } \\
\text { (Bloch, 1791) }\end{array}$ & $\mathrm{V}$ & $\begin{array}{l}\text { A single record from the lagoon. Indo- } \\
\text { Central Pacific. }\end{array}$ & & LC \\
\hline $\begin{array}{l}\text { Hologymnosus annulatus } \\
\text { (Lacepede, 1801) }\end{array}$ & $\mathrm{P}$ & $\begin{array}{l}\text { A single record from the lagoon. Indo- } \\
\text { Pacific. }\end{array}$ & & LC \\
\hline $\begin{array}{l}\text { Labrichthys unilineatus } \\
\text { (Guichenot, 1847). }\end{array}$ & $\mathrm{P}$ & Recorded from the lagoon. Indo-Pacific & & LC \\
\hline $\begin{array}{l}\text { Labroides bicolor } \\
\text { (Fowler \& Bean, 1928) }\end{array}$ & $\mathrm{V}$ & Recorded from the lagoon. Indo-Pacific. & & LC \\
\hline $\begin{array}{l}\text { Labroides dimidiatus } \\
\text { (Valenciennes, 1839) }\end{array}$ & $\mathrm{V} / \mathrm{S}$ & $\begin{array}{l}\text { Common throughout the lagoon. Indo- } \\
\text { Pacific. }\end{array}$ & $75 ; 85 \mathrm{TL}$ & LC \\
\hline $\begin{array}{l}\text { Novaculichthys } \\
\text { taeniourus (Lacepede, } \\
\text { 1801) }\end{array}$ & $\mathrm{V}$ & Recorded from the lagoon. Indo-Pacific. & & LC \\
\hline $\begin{array}{l}\text { Pseudocheilinus evanidus } \\
\text { (Jenkins, 1901) }\end{array}$ & $\mathrm{V}$ & Recorded from the lagoon. Indo-Pacific. & & LC \\
\hline $\begin{array}{l}\text { Pseudocheilinus } \\
\text { hexataenia (Bleeker, } \\
\text { 1857) }\end{array}$ & $\mathrm{P} \& \mathrm{~S}$ & Lagoon. Indo-Pacific. & $\begin{array}{l}55 ; 55 ; 55 ; 56 ; 58 \\
\text { TL }\end{array}$ & LC \\
\hline $\begin{array}{l}\text { Stethojulis albovittata } \\
\text { (Bonaterre, 1788) }\end{array}$ & $\mathrm{P} \& \mathrm{~S}$ & Lagoon. Indian Ocean. & $\begin{array}{c}0 ; 85 ; 85 ; 92 ; 96 ; \\
100 ; 100 ; \\
103 ; 112 \mathrm{FL} \\
\end{array}$ & LC \\
\hline $\begin{array}{l}\text { Thalassoma } \\
\text { amblycephalum (Bleeker, } \\
\text { 1856) }\end{array}$ & $\mathrm{P} \& \mathrm{~S}$ & $\begin{array}{l}\text { Common over bommies in the lagoon and } \\
\text { shallower areas of the drop-off. Indo- } \\
\text { Pacific. }\end{array}$ & $\begin{array}{l}\text { 70;74;75;76;78; } \\
90 \mathrm{TL}\end{array}$ & LC \\
\hline $\begin{array}{l}\text { Thalassoma hardwicke } \\
\text { (Bennett, 1828) }\end{array}$ & $\mathrm{P} \& \mathrm{~S}$ & $\begin{array}{l}\text { Common on the reeftop and in the lagoon. } \\
\text { Indo-Pacific. }\end{array}$ & $\begin{array}{c}82 ; \\
92 ; 100 ; 100 ; 105 \\
; 110 ; 110 \mathrm{TL} \\
\end{array}$ & LC \\
\hline $\begin{array}{l}\text { Thalassoma herbraicum } \\
\text { (Lacepede, 1801) }\end{array}$ & $\mathrm{P}$ & $\begin{array}{l}\text { Common on the reeftop and the lagoon. } \\
\text { Indian Ocean. }\end{array}$ & & LC \\
\hline $\begin{array}{l}\text { Thalassoma lunare } \\
\text { (Linnaeus, 1758) }\end{array}$ & $\mathrm{P} / \mathrm{S}$ & $\begin{array}{l}\text { Common on the reeftop and the lagoon. } \\
\text { Indo-Pacific. }\end{array}$ & $200 \mathrm{FL}$ & LC \\
\hline $\begin{array}{l}\text { Thalassoma purpureum } \\
\text { (Forsskal, 1775) }\end{array}$ & $\mathrm{V}$ & Recorded from the reeftop. Indo-Pacific. & & LC \\
\hline
\end{tabular}




\begin{tabular}{|c|c|c|c|c|}
\hline Family and Species & Method & Habitat Notes & $\begin{array}{l}\text { Specimen Size } \\
(\mathbf{m m})\end{array}$ & $\begin{array}{l}\text { IUCN } \\
\text { Red } \\
\text { List } \\
\end{array}$ \\
\hline $\begin{array}{l}\text { Thalassoma trilobatum } \\
\text { (Lacepede, 1801) }\end{array}$ & $\mathrm{V}$ & Recorded from the reeftop. Indo-Pacific. & & $\mathrm{LC}$ \\
\hline $\begin{array}{l}\text { Xyrichthys (Iniistius) } \\
\text { pavo (Valenciennes, } \\
\text { 1840) }\end{array}$ & $\mathrm{V}$ & $\begin{array}{l}\text { A single record from the lagoon. Indo- } \\
\text { Pacific. }\end{array}$ & & $\mathrm{LC}$ \\
\hline SCARIDAE & & PARROTFISHES & & \\
\hline $\begin{array}{l}\text { Cetoscarus bicolor } \\
\text { (Ruppell, 1828) }\end{array}$ & $\mathrm{V}$ & Recorded from the drop-off. Indo-Pacific. & & $\mathrm{LC}$ \\
\hline $\begin{array}{l}\text { Bolbometopon muricatum } \\
\text { (Valenciennes, 1840) }\end{array}$ & $\mathrm{V}$ & $\begin{array}{l}\text { Several adults recorded from the drop-off. } \\
\text { Indo-Pacific. }\end{array}$ & & $\mathbf{V U}$ \\
\hline $\begin{array}{l}\text { Hipposcarus harid } \\
\text { (Forsskal, 1775) }\end{array}$ & $\mathrm{V}$ & Recorded from the lagoon. Indian Ocean. & & $\mathrm{LC}$ \\
\hline $\begin{array}{l}\text { Scarus gibbus (Ruppell, } \\
1828 \text { ) }\end{array}$ & V & Quite common in the lagoon. Indo-Pacific. & & $\mathrm{LC}$ \\
\hline $\begin{array}{l}\text { Scarus frenatus } \\
\text { (Lacepede, 1802) }\end{array}$ & $\mathrm{P}$ & $\begin{array}{l}\text { Recorded from both the lagoon and drop- } \\
\text { off. Identity confirmed by Phillip C. } \\
\text { Heemstra. Indo-Pacific. }\end{array}$ & & $\mathrm{LC}$ \\
\hline $\begin{array}{l}\text { Scarus enneacanthus } \\
\text { (Lacepede, 1802) }\end{array}$ & P\&S. & $\begin{array}{l}\text { Previously considered rare (Smith \& } \\
\text { Heemstra, 1986). Shoals (10-20) were } \\
\text { common on the sheltered north-west drop- } \\
\text { off in mid water. Identity confirmed by P. } \\
\text { Heemstra and J. Randall. Central and } \\
\text { Western Indian Ocean. RUSI No:037368 }\end{array}$ & $200 ; 200 \mathrm{TL}$ & $\mathrm{LC}$ \\
\hline $\begin{array}{l}\text { Scarus ghobban } \\
\text { (Forsskal, 1775) }\end{array}$ & $\mathrm{V} \& \mathrm{P}$ & $\begin{array}{l}\text { Common in the lagoon and on the reeftop } \\
\text { in shallow water where large adults } \\
\text { frequently become stranded by the receding } \\
\text { tide. Indo-Pacific. }\end{array}$ & & $\mathrm{LC}$ \\
\hline Scarus sordidus (?) & $\mathrm{V} \& \mathrm{~S}$ & $\begin{array}{l}\text { Reef top- many juveniles in pools; RUSI } \\
\text { No:043311 }\end{array}$ & 1 specimen & \\
\hline $\begin{array}{l}\text { Scarus psittacus } \\
\text { (Forsskal, 1775) }\end{array}$ & $\mathrm{P} \& \mathrm{~S}$ & $\begin{array}{l}\text { Reeftop. Also recorded from the lagoon. } \\
\text { Indo-Pacific. RUSI No:037342 }\end{array}$ & $180 \mathrm{TL}$ & $\mathrm{LC}$ \\
\hline $\begin{array}{l}\text { Scarus rubroviolaceaus } \\
\text { (?) }\end{array}$ & $\mathrm{V}$ & $\begin{array}{l}\text { Common in lagoon; sometimes over drop } \\
\text { off. }\end{array}$ & & $\mathrm{LC}$ \\
\hline $\begin{array}{l}\text { Scarus russelii } \\
\text { (Valenciennes, 1840) }\end{array}$ & $\mathrm{P}$ & $\begin{array}{l}\text { Lagoon. Identified from photo by Jack } \\
\text { Randall. Central and West Indian Ocean }\end{array}$ & 1 specimen & $\mathrm{LC}$ \\
\hline SPHYRAENIDAE & & BARRACUDAS & & \\
\hline $\begin{array}{l}\text { Sphyraena barracuda } \\
\text { (Walbaum, 1792) }\end{array}$ & $\mathrm{P} \& \mathrm{~V}$ & $\begin{array}{l}\text { Large individuals up to } 1,5 \text { metres seen } \\
\text { patrolling on the deeper drop-offs. } \\
\text { Common. Circumtropical. }\end{array}$ & & $\mathrm{LC}$ \\
\hline $\begin{array}{l}\text { Sphyraena qenie } \\
\text { (Klunzinger, 1870) }\end{array}$ & $\mathrm{V} \& \mathrm{C}$ & $\begin{array}{l}\text { A single specimen taken by spear in the } \\
\text { lagoon but not kept. Indo-Pacific. }\end{array}$ & $850 \mathrm{FL}$ & $\mathrm{NE}$ \\
\hline MUGILOIDIDAE & & SANDPERCHES & & \\
\hline $\begin{array}{l}\text { Parapercis hexophthalma } \\
\text { (Ehrenberg, 1829) }\end{array}$ & $\mathrm{S}$ & Lagoon. Indo-West Pacific. & $210 \mathrm{TL}$ & $\mathrm{NE}$ \\
\hline $\begin{array}{l}\text { Parapercis punctulata } \\
\text { (Cuvier, 1829) }\end{array}$ & V & $\begin{array}{l}\text { Recorded from the lagoon and on the drop- } \\
\text { off at } 20 \text { metres. Western Indian Ocean. }\end{array}$ & & $\mathrm{NE}$ \\
\hline
\end{tabular}




\begin{tabular}{|c|c|c|c|c|}
\hline BLENIIDAE & & BLENNIES & & \\
\hline $\begin{array}{l}\text { Aspidontus taeniatus } \\
\text { tractus (Fowler, 1903) }\end{array}$ & $\mathrm{V}$ & Recorded from the lagoon. Indian Ocean. & & $\mathrm{LC}$ \\
\hline $\begin{array}{l}\text { Cirripectes castaneus } \\
\text { (Valenciennes, 1836) }\end{array}$ & $\mathrm{V} \& \mathrm{~S}$ & Reeftop. Indo-West Pacific. & $50 ; 80 \mathrm{TL}$ & $\mathrm{LC}$ \\
\hline $\begin{array}{l}\text { Cirripectes perustus } \\
\text { (Smith, 1959) }\end{array}$ & $\mathrm{V} \& \mathrm{~S}$ & Collected from reeftop. RUSI No:043306 & 3 specimens & $\mathrm{LC}$ \\
\hline $\begin{array}{l}\text { Ecsenius midas (Starck, } \\
\text { 1969) }\end{array}$ & $\mathrm{V}$ & $\begin{array}{l}\text { Recorded from the lagoon. Indo-West } \\
\text { Pacific. }\end{array}$ & & $\mathrm{LC}$ \\
\hline $\begin{array}{l}\text { Ecsenius bicolor (Day, } \\
1888 \text { ) }\end{array}$ & $\mathrm{V}$ & $\begin{array}{l}\text { Recorded from the reeftop. Indo-West } \\
\text { Pacific. }\end{array}$ & & $\mathrm{LC}$ \\
\hline $\begin{array}{l}\text { Exallias brevis (Kner, } \\
1868)\end{array}$ & $\mathrm{V}$ & $\begin{array}{l}\text { Recorded from bommies in lagoon. Indo- } \\
\text { Central Pacific. }\end{array}$ & & $\mathrm{LC}$ \\
\hline $\begin{array}{l}\text { Istiblennius edentulus } \\
\text { (Schneider, 1801) }\end{array}$ & V\&S & Common on reeftop & $105 \mathrm{TL}$ & $\mathrm{LC}$ \\
\hline $\begin{array}{l}\text { Istiblennius } \\
\text { periophthalmus } \\
\text { (Valenciennes, 1836) }\end{array}$ & $\mathrm{V} \& \mathrm{~S}$ & $\begin{array}{l}\text { The most common blenny on the reeftop. } \\
\text { Indo-Pacific. }\end{array}$ & $\begin{array}{c}63 ; 90 ; 105 ; 108 ; \\
120 ; 130 ; 141 ; \\
165 ; 170 ; 175 \mathrm{TL} \\
\end{array}$ & $\mathrm{LC}$ \\
\hline $\begin{array}{l}\text { Plagiotremus } \\
\text { rhinorhynchos (Bleeker, } \\
1853 \text { ) }\end{array}$ & $\mathrm{V}$ & Recorded from the lagoon. Indo-Pacific. & & $\mathrm{LC}$ \\
\hline $\begin{array}{l}\text { Plagiotremus } \\
\text { tapeinosoma }(\text { Bleeker, } \\
1857)\end{array}$ & $\mathrm{V}$ & $\begin{array}{l}\text { Recorded from the reeftop and the lagoon. } \\
\text { Indo-Pacific. }\end{array}$ & & $\mathrm{LC}$ \\
\hline $\begin{array}{l}\text { Salarias fasciatus (Bloch, } \\
1786 \text { ) }\end{array}$ & V\&S & Reeftop. Indo-Pacific. RUSI No:043309 & 1 specimen & $\mathrm{LC}$ \\
\hline GOBIIDAE & & GOBIES & & \\
\hline Gnatholepis sp. & $\mathrm{P} \& \mathrm{~S}$ & Awaiting revision of this genus & & $\mathrm{NE}$ \\
\hline $\begin{array}{l}\text { Ctenogobius feroculus } \\
\text { (Lubbock \& Polunin, } \\
\text { 1977) }\end{array}$ & $\mathrm{P}$ & $\begin{array}{l}\text { One specimen. Identified by R. } \\
\text { Winterbottom. Recorded from the lagoon. } \\
\text { Indo-West Pacific. }\end{array}$ & & $\mathrm{LC}+$ \\
\hline $\begin{array}{l}\text { Favonogobius reichei? } \\
\text { (Bleeker, 1953) }\end{array}$ & $\mathrm{P} \& \mathrm{~S}$ & $\begin{array}{l}\text { Recorded from the lagoon. Awaiting ID } \\
\text { confirmation. }\end{array}$ & & $\mathrm{NE}$ \\
\hline $\begin{array}{l}\text { Istigobius ornatus } \\
\text { (Ruppell, 1830) }\end{array}$ & $\mathrm{S}$ & $\begin{array}{l}\text { Indo-Central Pacific. Awaiting ID } \\
\text { confirmation. }\end{array}$ & & $\mathrm{LC}$ \\
\hline $\begin{array}{l}\text { Nemateleotris magnifica } \\
\text { (Fowler, 1938) }\end{array}$ & $\mathrm{V}$ & $\begin{array}{l}\text { Recorded from the lagoon. Indo-Central } \\
\text { Pacific. }\end{array}$ & & $\mathrm{LC}$ \\
\hline $\begin{array}{l}\text { Paragobiodon } \\
\text { xanthosomus (Bleeker, } \\
1852 \text { ) }\end{array}$ & $\mathrm{S} / \mathrm{P}$ & Awaiting ID confirmation & & - \\
\hline $\begin{array}{l}\text { Ptereleotris evides } \\
\text { (Jordan \& Hubbs, 1925) }\end{array}$ & $\mathrm{V}$ & $\begin{array}{l}\text { Common in the lagoon over sand next to } \\
\text { bommies. Indo-West Pacific. }\end{array}$ & & $\mathrm{LC}$ \\
\hline $\begin{array}{l}\text { Ptereleotris heteroptera } \\
\text { (Bleeker, 1855) }\end{array}$ & $\mathrm{V}$ & $\begin{array}{l}\text { Recorded from the lagoon. Indo-Central } \\
\text { Pacific. }\end{array}$ & & $\mathrm{LC}$ \\
\hline $\begin{array}{l}\text { Valenciennea } \\
\text { helsdingenii (Bleeker, } \\
1858)\end{array}$ & $\mathrm{S}$ & $\begin{array}{l}\text { A single specimen collected from the } \\
\text { lagoon. Indo-Pacific. }\end{array}$ & & $\mathrm{LC}$ \\
\hline $\begin{array}{l}\text { Valenciennea strigata } \\
\text { (Broussonet, 1787) }\end{array}$ & $\mathrm{V}$ & Recorded from the lagoon. Indo-Pacific. & & $\mathrm{NE}$ \\
\hline
\end{tabular}




\begin{tabular}{|c|c|c|c|c|}
\hline Family and Species & Method & Habitat Notes & $\begin{array}{l}\text { Specimen Size } \\
(\mathbf{m m})\end{array}$ & $\begin{array}{l}\text { IUCN } \\
\text { Red } \\
\text { List } \\
\end{array}$ \\
\hline ACANTHURIDAE & & SURGEONFISHES & & \\
\hline $\begin{array}{l}\text { Acanthurus blochii } \\
\text { (Valenciennes, 1835) }\end{array}$ & $\mathrm{V}$ & Recorded from the drop-off. Indo-Pacific & & $\mathrm{LC}$ \\
\hline $\begin{array}{l}\text { Acanthurus dussumieri } \\
\text { (Valenciennes, 1835) }\end{array}$ & $\mathrm{P}$ & Common in the lagoon. Indo-Pacific. & & $\mathrm{LC}$ \\
\hline $\begin{array}{l}\text { Acanthurus leucosternon } \\
\text { (Bennett, 1832) }\end{array}$ & $\mathrm{P}$ & $\begin{array}{l}\text { Common in lagoon and on the drop-off. } \\
\text { Indo-West Pacific. }\end{array}$ & & $\mathrm{LC}$ \\
\hline $\begin{array}{l}\text { Acanthurus lineatus } \\
\text { (Linnaeus, 1758) }\end{array}$ & $\mathrm{V}$ & Common in the lagoon. Indo-Pacific. & & $\mathrm{LC}$ \\
\hline $\begin{array}{l}\text { Acanthurus mata (Cuvier, } \\
\text { 1829) }\end{array}$ & $\mathrm{V}$ & Recorded from the drop-off. Indo-Pacific. & & $\mathrm{LC}$ \\
\hline $\begin{array}{l}\text { Acanthurus nigricauda } \\
\text { (Duncker \& Mohr, 1929) }\end{array}$ & $\mathrm{S} \& \mathrm{~V}$ & Common in lagoon. & $210-230 \mathrm{FL}$ & $\mathrm{LC}$ \\
\hline $\begin{array}{l}\text { Acanthurus nigrofuscus } \\
\text { (Forsskal, 1775) }\end{array}$ & $\mathrm{S} \& \mathrm{~V}$ & $\begin{array}{l}\text { The most commonly encountered surgeon } \\
\text { in the lagoon and in pools on the reeftop. } \\
\text { Indo-Pacific. }\end{array}$ & $100 ; 110 \mathrm{FL}$ & $\mathrm{LC}$ \\
\hline $\begin{array}{l}\text { Acanthurus tennenti } \\
\text { (Gunther, 1861) }\end{array}$ & $\mathrm{V}$ & $\begin{array}{l}\text { Recorded from the lagoon. Western Indian } \\
\text { Ocean }\end{array}$ & & $\mathrm{LC}$ \\
\hline $\begin{array}{l}\text { Acanthurus thompsoni } \\
\text { (Fowler, 1923) }\end{array}$ & $\mathrm{V}$ & Recorded from the drop-off. Indo-Pacific. & & $\mathrm{LC}$ \\
\hline $\begin{array}{l}\text { Acanthurus triostegus } \\
\text { (Linnaeus, 1758) }\end{array}$ & $\mathrm{S} / \mathrm{V}$ & $\begin{array}{l}\text { Reeftop; in great numbers but mostly } \\
\text { confined to very shallow areas }\end{array}$ & $39 \times(60-95 \mathrm{FL})$ & $\mathrm{LC}$ \\
\hline $\begin{array}{l}\text { Acanthurus xanthopterus } \\
\text { (Valenciennes, 1835) }\end{array}$ & $\mathrm{V}$ & Recorded from the drop-off. Indo-Pacific. & & $\mathrm{LC}$ \\
\hline $\begin{array}{l}\text { Ctenochaetus striatus } \\
\text { (Quoy \& Gaimard, 1825) }\end{array}$ & $\mathrm{V}$ & $\begin{array}{l}\text { Recorded from the lagoon and reeftop. } \\
\text { Indo-Pacific. }\end{array}$ & & $\mathrm{LC}$ \\
\hline $\begin{array}{l}\text { Zebrasoma veliferum } \\
\text { (Bloch, 1797) }\end{array}$ & $\mathrm{V}$ & Recorded from the lagoon. Indo-Pacific. & & $\mathrm{LC}$ \\
\hline $\begin{array}{l}\text { Ctenochaetus strigosus } \\
\text { (Bennett, 1828) }\end{array}$ & $\mathrm{V}$ & Recorded from the lagoon. Indo-Pacific. & & $\mathrm{LC}$ \\
\hline $\begin{array}{l}\text { Zebrasoma gemmatum } \\
\text { (Valenciennes, 1835) }\end{array}$ & $\mathrm{V}$ & $\begin{array}{l}\text { Recorded from the drop-off. Western } \\
\text { Indian Ocean. }\end{array}$ & & $\mathrm{LC}$ \\
\hline $\begin{array}{l}\text { Zebrasoma flavescens } \\
\text { (Bennett 1828) }\end{array}$ & $\mathrm{V}$ & $\begin{array}{l}\text { A single specimen recorded from the } \\
\text { lagoon. Indo-West Pacific. }\end{array}$ & & $\mathrm{LC}$ \\
\hline $\begin{array}{l}\text { Zebrasoma scopas } \\
\text { (Cuvier 1829) }\end{array}$ & $\mathrm{V}$ & $\begin{array}{l}\text { A single specimen recorded from the } \\
\text { lagoon. Indo-West Pacific. }\end{array}$ & & $\mathrm{LC}$ \\
\hline $\begin{array}{l}\text { Naso annulatus (Quoy \& } \\
\text { Gaimard, 1825) }\end{array}$ & $\mathrm{V}$ & $\begin{array}{l}\text { Shoals numbering } 10-20 \text { fish seen foraging } \\
\text { on the reeftop at high tide. Indo-Pacific. }\end{array}$ & & $\mathrm{LC}$ \\
\hline $\begin{array}{l}\text { Naso brevirostris } \\
\text { (Valenciennes, 1835) }\end{array}$ & $\mathrm{V}$ & $\begin{array}{l}\text { Recorded from midwater on the drop-off. } \\
\text { Indo-Pacific }\end{array}$ & & $\mathrm{LC}$ \\
\hline $\begin{array}{l}\text { Naso hexacanthus } \\
\text { (Bleeker, 1855) }\end{array}$ & $\mathrm{V}$ & $\begin{array}{l}\text { Shoals numbering } 20 \text { to } 30 \text { fish seen in } \\
\text { midwater on the drop-off. Indo-Pacific. }\end{array}$ & & $\mathrm{LC}$ \\
\hline $\begin{array}{l}\text { Naso lituratus } \\
\text { (Schneider, 1801) }\end{array}$ & $\mathrm{V}$ & $\begin{array}{l}\text { Usually seen in pairs on the drop-off. Indo- } \\
\text { Pacific. }\end{array}$ & & $\mathrm{LC}$ \\
\hline ZANCLIDAE & & MOORISH IDOL & & \\
\hline $\begin{array}{l}\text { Zanclus canescens } \\
\text { (Linnaeus, 1758) }\end{array}$ & $\mathrm{V}$ & $\begin{array}{l}\text { Recorded from the lagoon and drop-off. } \\
\text { Indo-Pacific }\end{array}$ & & $\mathrm{LC}$ \\
\hline
\end{tabular}




\begin{tabular}{|c|c|c|c|c|}
\hline SIGANIDAE & & RABBITFISHES & & \\
\hline $\begin{array}{l}\text { Siganus stellatus } \\
\text { (Forsskal, 1775) }\end{array}$ & $\mathrm{V}$ & Recorded from the lagoon. Indo-Pacific. & & $\mathrm{LC}$ \\
\hline $\begin{array}{l}\text { Siganus sutor } \\
\text { (Valenciennes, 1835) }\end{array}$ & $\mathrm{V}$ & $\begin{array}{l}\text { Recorded from the lagoon. Western Indian } \\
\text { Ocean. }\end{array}$ & & $\mathrm{LC}$ \\
\hline SCOMBRIDAE & & TUNAS \& MACKERELS & & \\
\hline $\begin{array}{l}\text { Acanthocybium solandri } \\
\text { (Cuvier, 1831) }\end{array}$ & $\mathrm{V} \& \mathrm{C}$ & $\begin{array}{l}\text { Commonly caught on line over drop-off. } \\
\text { Cosmopolitan. }\end{array}$ & $1030 \mathrm{FL}$ & $\mathrm{LC}$ \\
\hline $\begin{array}{l}\text { Euthynnus affinis } \\
\text { (Cantor, 1849) }\end{array}$ & $\mathrm{V}$ & $\begin{array}{l}\text { Large shoals seen feeding on the surface in } \\
\text { the vicinity of the atoll. Indo-Pacific. }\end{array}$ & & $\mathrm{LC}$ \\
\hline $\begin{array}{l}\text { Gymnosarda unicolor } \\
\text { (Ruppell, 1836) }\end{array}$ & $\mathrm{V}$ & $\begin{array}{l}\text { Common. Large adults seen whilst diving } \\
\text { on the drop-off. Indo-West Pacific. }\end{array}$ & & $\mathrm{LC}$ \\
\hline $\begin{array}{l}\text { Katsuwonus pelamis } \\
\text { (Linnaeus, 1758) }\end{array}$ & $\mathrm{V}$ & $\begin{array}{l}\text { Feeding shoals recorded in the vicinity of } \\
\text { the atoll. Cosmopolitan. }\end{array}$ & & $\mathrm{LC}$ \\
\hline $\begin{array}{l}\text { Thunnus albacares } \\
\text { (Bonnaterre, 1788) }\end{array}$ & $\mathrm{V} \& \mathrm{C}$ & $\begin{array}{l}\text { Several caught over the drop-off. } \\
\text { Cosmopolitan. }\end{array}$ & $1500 \mathrm{FL}$ & NT \\
\hline BALISTIDAE & & TRIGGERFISHES & & \\
\hline $\begin{array}{l}\text { Balistapus undulatus } \\
\text { (Mungo Park, 1797) }\end{array}$ & $\mathrm{V}$ & $\begin{array}{l}\text { Recorded from the lagoon. Indo-West } \\
\text { Pacific. }\end{array}$ & & $\mathrm{LC}$ \\
\hline $\begin{array}{l}\text { Balistoides conspicillum } \\
\text { (Bloch \& Schneider, } \\
\text { 1801) }\end{array}$ & $\mathrm{V}$ & $\begin{array}{l}\text { Recorded from the lagoon and the drop-off. } \\
\text { Indo-West Pacific. }\end{array}$ & & $\mathrm{NE}$ \\
\hline $\begin{array}{l}\text { Balistoides viridescens } \\
\text { (Bloch \& Schneider, } \\
\text { 1801) }\end{array}$ & $\mathrm{V}$ & $\begin{array}{l}\text { Recorded from the lagoon and the drop-off. } \\
\text { Indo-West Pacific. }\end{array}$ & & $\mathrm{NE}$ \\
\hline $\begin{array}{l}\text { Melichthys indicus } \\
\text { (Randall \& Klausewitz, } \\
\text { 1973) }\end{array}$ & $\mathrm{V}$ & $\begin{array}{l}\text { Common around bommies in the lagoon. } \\
\text { Indian Ocean. }\end{array}$ & & $\mathrm{NE}$ \\
\hline $\begin{array}{l}\text { Melichthys niger (Bloch, } \\
1786)\end{array}$ & $\mathrm{V}$ & $\begin{array}{l}\text { Recorded from the lagoon. Less common } \\
\text { than the previous species. Circumtropical. }\end{array}$ & & $\mathrm{NE}$ \\
\hline $\begin{array}{l}\text { Pseudobalistes fuscus } \\
\text { (Bloch \& Schneider, } \\
\text { 1801) }\end{array}$ & $\mathrm{V}$ & $\begin{array}{l}\text { Recorded from the lagoon and the drop-off. } \\
\text { Indo-West Pacific. }\end{array}$ & & $\mathrm{NE}$ \\
\hline $\begin{array}{l}\text { Rhinecanthus aculeatus } \\
\text { (Linnaeus, 1758) }\end{array}$ & $\mathrm{V}$ & $\begin{array}{l}\text { Recorded from the lagoon and the reeftop. } \\
\text { Indo-West Pacific. }\end{array}$ & & NE \\
\hline $\begin{array}{l}\text { Rhinecanthus rectangulus } \\
\text { (Bloch \& Schneider, } \\
\text { 1801) }\end{array}$ & $\mathrm{V} \& \mathrm{~S}$ & Reeftop. Indo-West Pacific. & $140 \mathrm{TL}$ & \\
\hline $\begin{array}{l}\text { Sufflamen bursa }(\text { Bloch } \\
\& \text { Schneider, 1801) }\end{array}$ & $\mathrm{V}$ & $\begin{array}{l}\text { Recorded from the drop-off. Indo-West } \\
\text { Pacific. }\end{array}$ & & $\mathrm{LC}$ \\
\hline $\begin{array}{l}\text { Sufflamen chrysopterus } \\
\text { (Bloch \& Schneider, } \\
\text { 1801) }\end{array}$ & $\mathrm{V}$ & $\begin{array}{l}\text { Recorded from the drop-off. Indo-West } \\
\text { Pacific. }\end{array}$ & & $\mathrm{LC}$ \\
\hline MONACANTHIDAE & & BIGEYES & & \\
\hline $\begin{array}{l}\text { Cantherinnes dumerilii } \\
\text { (Hollard, 1854) }\end{array}$ & V\&S & $\begin{array}{l}\text { Recorded from lagoon \& the reeftop. Indo- } \\
\text { Pacific. }\end{array}$ & $125 \mathrm{TL}$ & $\mathrm{LC}$ \\
\hline $\begin{array}{l}\text { Paraluteres prionurus } \\
\text { (Bleeker, 1851) }\end{array}$ & $\mathrm{V}$ & $\begin{array}{l}\text { Recorded from the lagoon. Indo-West } \\
\text { Pacific. }\end{array}$ & & LC \\
\hline
\end{tabular}




\begin{tabular}{|c|c|c|c|c|}
\hline Family and Species & Method & Habitat Notes & $\begin{array}{l}\text { Specimen Size } \\
\quad(\mathbf{m m})\end{array}$ & $\begin{array}{c}\text { IUCN } \\
\text { Red } \\
\text { List } \\
\end{array}$ \\
\hline $\begin{array}{l}\text { Pervagor janthinosoma } \\
\text { (Bleeker, 1854) }\end{array}$ & $\mathrm{V}$ & $\begin{array}{l}\text { Recorded from the reeftop. Indo-West } \\
\text { Pacific. }\end{array}$ & & $\mathrm{LC}$ \\
\hline OSTRACIIDAE & & BOXFISHES & & \\
\hline $\begin{array}{l}\text { Ostracion cubicus } \\
\text { (Linnaeus, 1758) }\end{array}$ & $\mathrm{V}$ & $\begin{array}{l}\text { Recorded from the lagoon. Indo-West } \\
\text { Pacific. }\end{array}$ & & $\mathrm{LC}$ \\
\hline $\begin{array}{l}\text { Ostracion meleagris } \\
\text { (Shaw, 1796) }\end{array}$ & $\mathrm{V}$ & Recorded from the lagoon. Indo-Pacific. & & $\mathrm{LC}$ \\
\hline TETRAODONTIDAE & & PUFFERS & & \\
\hline $\begin{array}{l}\text { Arothron hispidus } \\
\text { (Linnaeus, 1758) }\end{array}$ & $\mathrm{V}$ & $\begin{array}{l}\text { Recorded from the lagoon. Common. Indo- } \\
\text { West Pacific. }\end{array}$ & & $\mathrm{LC}$ \\
\hline $\begin{array}{l}\text { Arothron meleagris } \\
\text { (Bloch \& Schneider, } \\
1801 \text { ) }\end{array}$ & $\mathrm{V}$ & $\begin{array}{l}\text { Recorded from the lagoon. Common. Indo- } \\
\text { West Pacific. }\end{array}$ & & $\mathrm{LC}$ \\
\hline $\begin{array}{l}\text { Arothron nigropunctatus } \\
\text { (Bloch \& Schneider, } \\
\text { 1801) }\end{array}$ & $\mathrm{V}$ & $\begin{array}{l}\text { Recorded from the lagoon. Common. Indo- } \\
\text { West Pacific. }\end{array}$ & & $\mathrm{LC}$ \\
\hline $\begin{array}{l}\text { Canthigaster } \\
\text { amboinensis (Bleeker, } \\
1865)\end{array}$ & $\mathrm{V}$ & $\begin{array}{l}\text { Recorded from the lagoon. Common. Indo- } \\
\text { West Pacific. }\end{array}$ & & $\mathrm{LC}$ \\
\hline $\begin{array}{l}\text { Canthigaster bennetti } \\
\text { (Bleeker, 1854) }\end{array}$ & $\mathrm{P} \& \mathrm{~S}$ & $\begin{array}{l}\text { Recorded from the lagoon. Indo-West } \\
\text { Pacific. }\end{array}$ & $65 \mathrm{TL}$ & $\mathrm{LC}$ \\
\hline $\begin{array}{l}\text { Canthigaster } \\
\text { janthinoptera (Bleeker, } \\
1855)\end{array}$ & $\mathrm{P} \& S$ & $\begin{array}{l}\text { Recorded from the lagoon. Indo-West } \\
\text { Pacific. }\end{array}$ & $57,65 \mathrm{TL}$ & $\mathrm{LC}$ \\
\hline $\begin{array}{l}\text { Canthigaster valentini } \\
\text { (Bleeker, 1853) }\end{array}$ & $\mathrm{V}$ & $\begin{array}{l}\text { Recorded from the lagoon. Common. Indo- } \\
\text { West Pacific. }\end{array}$ & & $\mathrm{LC}$ \\
\hline \multicolumn{5}{|l|}{ DIODONTIDAE } \\
\hline $\begin{array}{l}\text { Diodon hystrix } \\
\text { Linnaeus, } 1758\end{array}$ & $\mathrm{~V}$ & Recorded from the lagoon. Circumtropical. & & $\mathrm{LC}$ \\
\hline
\end{tabular}

